\title{
Potential Neuroprotective Effect of Clopidogrel on Aluminum Chloride-Induced Alzheimer Disease in Rats.
}

Noura El Adle Khalaf a, Rehab Hamdy Ashour a, Mona Younis Youssef b, Youssef Mohammed Mosaad c, Mohamed-Hesham Daba a, Farida Hanem Mohamed El Banna a

a Department of clinical pharmacology,

Faculty of Medicine, Mansoura University, Egypt

$b$ Department of pathology, Faculty of Medicine, Mansoura University, Egypt

${ }^{c}$ Department of clinical pathology, Faculty of Medicine, Mansoura University, Egypt

\begin{abstract}
Background and aim: Alzheimer's disease (AD) is a common progressive disease characterized by neurodegeneration. Multiple molecular mechanisms such as amyloid $\beta(A \beta)$ formation, tau protein hyperphosphorylation, reduced cholinergic neurotransmission, oxidative stress, and neuroinflammation are involved in the disease pathophysiology. The purpose of this study was to assess potential neuroprotective effect of clopidogrel in $A D$ model induced by aluminum chloride $(\mathrm{AICl} 3)$ in rats

Methods:
\end{abstract}

Forty adult male Sprague-Dawley rats were haphazardly separated into four groups of ten rats each: Control, $\mathrm{AlCl} 3$ (100 mg/kg orally), AlCl3 + Memantine $(10 \mathrm{mg} / \mathrm{kg}$ orally), and $\mathrm{AlCl} 3+$ Clopidogrel groups $(20 \mathrm{mg} / \mathrm{kg}$ orally). $\mathrm{AlCl} 3$ and drugs were administrated once every day for 42 days. The spatial learning and memory were evaluated using Morris Water Maze (MWM) test. After euthanization, hippocampal acetylcholinesterase (AChE) activity, tumor necrosis factor alpha (TNF- $\alpha$ ), and interleukin-1 beta (IL-1 $\beta$ ) concentrations were biochemically assessed in all groups. Moreover, amyloid precursor protein (APP) mRNA gene expression was analyzed in the hippocampus of all groups with Real-time quantitative polymerase chain reaction (qPCR). Histopathology for amyloid plaques was done in all groups' hippocampus using hematoxylin and eosin and Congo stain.

Results: $\mathrm{AlCl}_{3}$ and clopidogrel co-treatment significantly ameliorated the cognitive deficits induced by $\mathrm{AICl} 3$ in rats. Moreover, $\mathrm{AICl} 3$ and clopidogrel co-treatment significantly reduced AChE activity, TNF- $\alpha$ and IL-1 $\beta$ concentrations, and APP mRNA gene expression in the rat hippocampi compared to AICl3-treated rats. $\mathrm{AICl} 3$ and clopidogrel co-treatment significantly reduced TNF- $\alpha$ and IL-1 $\beta$ concentrations in the rat hippocampi compared to $\mathrm{AICl} 3$ and memantine co-treated rats. In addition, $\mathrm{AICl} 3$ and clopidogrel cotreatment alleviated amyloid plaque deposition in the rat hippocampal tissues stained with hematoxylin and eosin and Congo stains compared to AICl3-treated rats.

Conclusion: These results showed that clopidogrel could improve cognitive deficits triggered by $\mathrm{AlCl}_{3}$ in rats. The neuronal protection influence of clopidogrel in $\mathrm{AlCl}$-triggered $A D$ might be mediated through its antiinflammatory effect as demonstrated by its ability to decrease hippocampal TNF- $\alpha$ and IL-1 $\beta$ concentrations. It might also be mediated through its lowering effect on AChE activity and/or decreasing mRNA gene expression of APP gene in the hippocampus

Keywords: Alzheimer's disease, Neuroinflammation, Clopidogrel, Aluminum chloride 


\section{Introduction}

Alzheimer's disease (AD) is a rapidly deteriorated disease prevalent all over the world, characterized by neurodegeneration, but yet with no effective cure (Chen et al, 2018). The pathogenesis of this disease is still unclear. Many hypotheses have been proposed for $A D$, involving amyloid $\beta$ $(A \beta)$ deposition, tau protein hyperphosphorylation, cholinergic nerve cell destruction, neuroinflammation, oxidative stress, etc. (Du et al, 2018). The pathological hallmarks observed in $A D$ brain include extracellular amyloid plaques and intracellular neurofibrillary tangles (NFTs). Clinically, AD patients suffer from learning and memory deficits, and neuropsychiatric and behavior changes (Chen et al, 2018).

Cholinesterase inhibitors donepezil, galantamine and rivastigmine and the $\mathrm{N}$-methyl-Daspartate (NMDA) receptor blocker memantine are the only food and drug administration (FDA) approved AD treatments (Kim et al, 2017). These approved drugs provide only symptomatic relief and haven't shown to prevent or delay the progression of disease (Deardorff \& Grossberg, 2016). Therefore, seeking effective diseasemodifying therapeutics with multiple targets is highly desirable (Chen et al, 2018).

The current study aimed to evaluate potential neuronal protection effect of clopidogrel in aluminum chloride ( $\mathrm{AICl} 3$ )-triggered $A D$ in rats and compare it with the effect of memantine. It also aimed to understand its possible mechanism(s) for neuroprotection.

\section{Material and Methods}

Chemicals and drugs

Aluminum chloride anhydrous (molecular weight: $133.332 \mathrm{~g} / \mathrm{mol}$ ) was purchased from ElGomhouria Chemical Company, Mansoura, Egypt. Memantine hydrochloride was used in the form of Ebixa tablets (manufactured by Lundbeck company, Denmark). Clopidogrel bisulphate was used in the form of Plavix tablets (manufactured by Sanofi- Aventes company, France).

\section{Experimental animals}

Adult male Sprague-Dawley rats were utilized at the study beginning with a weight of $200-250 \mathrm{~g}$. They were obtained from the Medical Experimental Research Center (MERC), Mansoura Faculty of Medicine. For seven days before the study, the animals were adapted to ordinary laboratory circumstances; adjusted temperature $\left(23 \pm 2^{\circ} \mathrm{C}\right)$, humidity $(50 \pm 5 \%)$ and 12 hours cyclic exposure to light and dark. The animals were housed in plastic cages lined with sawdust that was renewed daily and were freely fed on food and water ad libitum. These entire manipulations were performed in the daylight between 09.00 a.m. and 5.00 p.m.

\section{Animal care and ethical approval}

Laboratory animal handling was done according to the "Guide for the Care and Use of Laboratory Animals" organized by the institute of Laboratory Animal Research and issued by the National Research Council, USA, 2011 (Albus, 2012). The study design and protocol were reviewed and accepted by Mansoura Faculty of Medicine, Institutional Research Board (IRB) under the code of MD15.08.06.

\section{Experimental design}

Forty adult male Sprague-Dawley rats were haphazardly separated into four groups (ten rats each): Control group: administrated the vehicle for $\mathrm{AICl} 3$ (distilled water) daily orally for 42 days. $\mathrm{AlCl}_{3}$ group: received $\mathrm{AlCl}_{3}, 100 \mathrm{mg} / \mathrm{kg}$ daily orally for 42 days. $\mathrm{AlCl} 3+$ Memantine group: received $\mathrm{AlCl}_{3}, 100 \mathrm{mg} / \mathrm{kg}$ and memantine hydrochloride, $10 \mathrm{mg} / \mathrm{kg}$ (Ahmed et al, 2014) daily orally for 42 days. $\mathrm{AlCl}_{\mathbf{3}}+$ Clopidogrel group: administrated $\mathrm{AlCl}_{3}, 100 \mathrm{mg} / \mathrm{kg}$ and and clopidogrel bisulphate, $20 \mathrm{mg} / \mathrm{kg}$ (Tu et al, 2008) daily orally for 42 days. 
The drugs were introduced by mouth $1 \mathrm{~h}$ after $\mathrm{AICl} 3$ treatment and continued for 42 days (6 weeks) (Kumar et al, 2009). The $\mathrm{AlCl} 3$ dose used was choosen depending on an earlier study (Thippeswamy et al., 2013) and a pilot study in our laboratory that showed $\mathrm{AICl} 3$ in a dosage of $100 \mathrm{mg} / \mathrm{kg}$ was associated with the most obvious pathological characteristics of AD especially amyloid plaques. The mortality rate with AICl3 (100 $\mathrm{mg} / \mathrm{kg}$ ) was about $20 \%$. Other groups showed mortality rates of $0-10 \%$.

\section{Evaluation of learning and memory by Morris Wa-} ter Maze (MWM) test

Morris Water Maze is formed of a big circular pool (its diameter is $150 \mathrm{~cm}$, its height is $45 \mathrm{~cm}$ ) filled with water at $28 \pm 1^{\circ} \mathrm{C}$ to $30 \mathrm{~cm}$ depth and divided into four equivalent quadrants (N, S, E, and $W$ ) by two strands fixed at right angles. The pool was positioned in an illumined test chamber. In any pool quadrant, a circular platform (its diameter is $4.5 \mathrm{~cm}$ ) was positioned, $1 \mathrm{~cm}$ above the water level by $1 \mathrm{~cm}$ during the acquisition stage. This platform was positioned below the water level by $1 \mathrm{~cm}$ during the retention stage. The platform location was constant in the same quadrant during evaluation of both stages (Kumar et al, 2011). The water was made opaque during the retention phase by adding a nontoxic dye e.g. starch. During the test the rats were trained to avoid swimming by jumping onto the platform and by time the rats seemingly learn the spatial platform site from any beginning site at the pool circumference (Prashar et al, 2014).

\section{a) Maze acquisition phase (training)}

On day 20, animals were trained four times with 5 minutes interval in between. During the four training sessions, dissimilar beginning sites $(\mathrm{N}, \mathrm{S}$, $\mathrm{E}$, and $\mathrm{W}$ ) were used. A trial was initiated by introducing the animal into the maze fronting the pool wall and the delay to discover and jump onto the platform was noted to a 90 second maximum. If the rat did not jump onto the platform within 90 seconds, it was carried and directed to the platform and was kept there for 20 seconds. The initial acquisition latency (IAL) was described as the time consumed by the animal to jump on the platform (Ramachandran et al, 2013; Thippeswamy et al, 2013).

b) Maze retention phase (testing for retention of learned task)

After the four training sessions, the time consumed to discover and reach the hidden platform (retention latency "RL") was recorded and evaluated on day 21 ( $\left.1^{\text {st }} R L\right)$ and day $42\left(2^{\text {nd }} R L\right)$. The alteration in $R L$ from day 21 to day 42 was utilized to assess the acquired skill or memory (Ramachandran et al, 2013; Thippeswamy et al, 2013).

\section{Brain Tissue Sampling and Preparation}

When the study was finished, rats were deprived from food and water in the whole night, then euthanized by decapitation following intraperitoneal thiopental sodium injection $(40 \mathrm{mg} / \mathrm{kg}$ ) (IACUC Guidelines: Anesthesia. The university of Lowa, Office of Animal Resources, Institutional Animal Care and Use Committee, 2017). The skull was opened with cautious and each rat's entire brain was quickly taken out and cut mid-sagittally into two hemispheres. Hippocampus was micro-separated out from each hemisphere according to procedure documented previously (Carleton et al, 1980).

Hippoccampal halves from rats of each group were used as follows:

They were further equally divided to be processed either: 1) cleaned with ice-cold saline to eliminate blood, quickly kept in eppendorf tubes, embedded in liquid nitrogen and stored at $-80^{\circ} \mathrm{C}$ till its usage for Real-time quantitative polymerase chain reaction (qPCR) (Balgoon et al, 2015) or 2) cleaned with isotonic saline, desiccated on filter 
paper, and weighed then immediately homogenized in frozen phosphate-buffered saline at $\mathrm{pH}$ 7.4. Centrifugation of the homogenate was done at 2000-3000 rpm for $20 \mathrm{~min}$ at $4^{\circ} \mathrm{C}$ and the supernatant was separated and stored at $-20^{\circ} \mathrm{C}$ until its usage for biochemical estimations.

Other hippoccampal halves were kept in 10\% neutral buffered formalin to be fixed and then examined histopathologically by hematoxylin and eosin and Congo stains (Balgoon et al, 2015).

\section{Biochemical Estimations}

Rat hippocampal tissue homogenate was used to evaluate acetyl cholinesterase (AChE) activity by AChE Assay Kit (Colorimetric) (Abcam Co., UK, Cata. No.: ab138871) according to their manufacturer's instructions. In addition, tumor necrosis factor alpha (TNF- $\alpha$ ) and interleukin-1beta (IL-1 $\beta$ ) concentrations were estimated in rat hippocampal tissue homogenate using rat enzyme linked immunosorbent assay (ELISA) kits (Bioneovan Co. Ltd., China, Catalog. No. In-Ra1371 for TNF- $\alpha$, Catalog. No.: In-Ra0668 for IL-1 $\beta$ ) according to their manufacturer's instructions.

Real-time quantitative reverse transcriptionpolymerase chain reaction (Real-time qRT-PCR) for amyloid precursor protein (APP) gene expression determination in rat hippocampus

Entire RNA was taken out from rat hippocampal tissue samples in all groups by RNeasy Mini kit (Qiagen, Valencia, CA, USA) according to manufacturer's instruction. NanoDrop ${ }^{\circledR}$ ND-1000 Spectrophotometer (NanoDrop Technologies, Wilmington, Delaware, USA) was used to detect quantity and purity of every RNA sample using 260 and 260/280 nm ratio respectively. RNA sample purity was detected and it ranged from 1.8 to 2.1 indicating its high quality. RNA was reversetranscribed into complementary DNA (cDNA) using Arktik Thermal Cycler (Thermo Fisher Scientific Inc., MA, USA) and quantified using infra-red specific primer by Real-time PCR System (Applied Biosystems, Foster City, CA, USA). The primers were manufactured by Primers Biosearch technologies (Primers Biosearch technologies, CA, USA) and the specific gene sequences were obtained from Pubmed (Entrez Gene). The primers utilized in this experiment included $B$-actin (the control gene) $F$ : 5'CCCATCTATGAGGGTTACGC-3`; B-actin R: $5{ }^{`}$ TTTAATGTCACGCACGATTTC-3' (Zhou et al, 2009); APP (the studied gene) F: 5`TGGGTTGACAAACATCAAGACAGAA-3`; APP R: 5'-GCACCTTTGTTTGAACCCACATC-3 (Ying-Cai et al, 2007). The thermal cycling conditions were adjusted as follow: $15 \mathrm{~min}$ at $95{ }^{\circ} \mathrm{C}$ for DNA polymerase stimulation and subsequently 40 cycles of 15 seconds at $95{ }^{\circ} \mathrm{C}, 20$ seconds at 60 ${ }^{\circ} \mathrm{C}$ and 20 seconds at $72{ }^{\circ} \mathrm{C}$.

mRNA expression's relative quantification (RQ) was detected with the 2- $\triangle \triangle \mathrm{Ct}$ method (Schmittgen \& Livak, 2008). The data were presented as target mRNA relative quantity, normalized respect to $B$-actin mRNA and relative to a calibrator sample. Normal control samples were used as calibrators. Where: $\triangle \mathrm{Ct}=(\mathrm{Ct}$ of target gene $-\mathrm{Ct}$ of reference gene $) ; \Delta \triangle \mathrm{Ct}=(\Delta \mathrm{Ct}$ of sample $-\triangle \mathrm{Ct}$ of control). $\mathrm{Ct}$ is defined as the fractional cycle number at which the fluorescence passes the fixed threshold.

\section{Histopathological examination}

Rat brain hippocampus specimens were kept in $10 \%$ formalin for 24 hours to be fixed and subsequently cleaned with tap water. Sequential alcohol dilutions were used for desiccation. Specimens were cleaned in xylene immersed in paraffin in hot air oven at $56^{\circ} \mathrm{C}$ for 24 hours. Paraffin bees wax tissue block preparation was performed to be divided by microtome at 4 microns thickness. The resulting tissue slices were put on glass slides, cleared from paraffin and stained with hematoxylin and eosin stain for histopatho- 
logical examination under light microscopy (Ali et al, 2016). Congo red staining was done consistent with the manufacture's strategy. The hippocampal slice was put a slide and desiccated in air. The slice was embedded first in $80 \%$ ethanol containing $4 \%$ sodium chloride for 1 hours, then embedded in $80 \%$ ethanol containing $0.2 \%$ Congo red at room temperature for 1 hours. The sections were cover slipped and examined under light microscope (Guo et al, 2015).

\section{Statistical Analysis}

The results were statistically analyzed using Statistical Package for Social Science (SPSS) program, version 23.0, for windows 10. Charts were done using SPSS and/ or Excel program (Microsoft Excel, version 14.0.4734.1000, 2010). The parametric results were expressed as Mean \pm SD. One-way analysis of variance (ANOVA) followed by Tukey's post hoc multiple comparisons were used for statistical analysis between groups. Repeated measures ANOVA followed by post-hoc Bonferroni test were used for analyzing MWM data (IAL, $1^{\text {st }} \mathrm{RL}$, and $2^{\text {nd }} \mathrm{RL}$ ) within groups. $P$ value $<0.05$ indicate statistical significance.

\section{Results :}

Effect of memantine or clopidogrel on memory function in spatial navigation task of Morris Water Maze (MWM) test in aluminum chloride (A/Cl3)treated rats

In the spatial navigation task of MWM test, control rats were educated to directly swim to the visible platform rapidly on the day 20 . AICl3treated rats demonstrated a significant rise in mean IAL to jump onto the visible platform when compared to control rats on the day 20 ( $p<$ 0.001). On the other hand, concomitant administration of memantine or clopidogrel with $\mathrm{AICl} 3$ significantly reduced the IAL to jump onto the visible platform when compared to AlCl3-treated rats on the day 20 ( $p<0.001)$, Figure 1.
After the four training sessions, the visible platform was hidden. AlCl3-treated rats demonstrated a significant increase in mean $1^{\text {st }}$ and $2^{\text {nd }} \mathrm{RLS}$ when compared to control rats on the days 21 and 42 , respectively. $(\mathbf{p}<\mathbf{0 . 0 0 1})$. However, concomitant administration of memantine or clopidogrel with $\mathrm{AlCl} 3$ demonstrated a significant decrease in the $1^{\text {st }}$ and $2^{\text {nd }} \mathrm{RLs}$ when compared to AlCl3-treated rats on the days 21 and 42, respectively $(\mathbf{p}<0.001)$, Figure 1.

Effect of memantine or clopidogrel on acetylcholinesterase (AChE) activity, and tumor necrosis factor- $\alpha$ (TNF- $\alpha)$ and interleukin-1 $\beta$ (IL-1 $\beta$ ) concentrations in hippocampus of aluminum chloride (A/Cl3)-treated rats

Continuous $\mathrm{AICl} 3$ administration to rats demonstrated a significant rise in rat hippocampal AChE activity when compared to control rats ( $p$ $<\mathbf{0 . 0 0 1}$ ). However, concomitant administration of memantine or clopidogrel with $\mathrm{AlCl} 3$ significantly attenuated the rise in AChE activity when compared to $\mathrm{AlCl} 3$-treated rats $(\mathrm{p}<\mathbf{0 . 0 0 1})$. Rat hippocampal AChE activity in $\mathrm{AICl} 3+$ memantine group or $\mathrm{AlCl} 3+\mathrm{Clopidogrel}$ was still significantly raised when compared to control group ( $\mathbf{p}<\mathbf{0 . 0 0 1 )}$; but not significantly changed when compared to each other $(p=0.96)$, Table 1 .

Continuous $\mathrm{AlCl}_{3}$ administration to rats demonstrated a significant rise in the rat hippocampal TNF- $\alpha$ and IL- $1 \beta$ concentrations when compared to control rats $(\mathbf{p}<\mathbf{0 . 0 0 1})$. However, concomitant administration of memantine or clopidogrel with AICl3 significantly decreased rat hippocampal TNF- $\alpha$ and IL-1 $\beta$ concentrations when compared to the AICl3-treated rats $(\mathbf{p}<\mathbf{0 . 0 0 1})$. In addition, $\mathrm{AICl} 3$ and clopidogrel co-treatment significantly decreased rat hippocampal TNF- $\alpha$ and IL-1 $\beta$ concentrations when compared to $\mathrm{AICl} 3$ and memantine co-treatment $(p<0.01)$. Rat hippocampal TNF- $\alpha$ and IL- $1 \beta$ concentrations in $\mathrm{AICl} 3+$ memantine group were still significantly raised when compared to control group ( $\mathbf{p}<\mathbf{0 . 0 0 1 )}$; while, 
TNF- $\alpha$ and IL- $1 \alpha$ concentrations in $\mathrm{AlCl}_{3}+$ clopidogrel group were not significantly raised when compared to control group $(\mathbf{p}=\mathbf{0 . 7 5}$ and $\mathbf{p}=\mathbf{0 . 0 7}$ respectively), Table 1.

Effect of memantine or clopidogrel on relative quantification (RQ) of amyloid precursor protein (APP) mRNA gene expression in hippocampus of aluminum chloride (A/C/3)-treated rats

Continuous $\mathrm{AICl} 3$ administration to rats demonstrated a significant rise in the rat hippocampal APP gene expression when compared to control rats $(\mathbf{p}<\mathbf{0 . 0 0 1})$. However, concomitant administration of memantine or clopidogrel with $\mathrm{AlCl} 3$ significantly decreased rat hippocampal APP gene expression when compared to the AICl3-treated rats $(p<0.001)$. The rat hippocampal APP gene expressions of $\mathrm{AlCl} 3+$ memantine group or $\mathrm{AlCl} 3+$ clopidogrel group are still significantly raised when compared to control group ( $p<0.001$ ) but not significantly different when compared to each other, Table 1.

Effect of memantine or clopidogrel on histopathological examination in hippocampus of aluminum chloride (AlCl3)-treated rats

Examination of the hippocampus of $\mathrm{AlCl} 3$ group by hematoxylin and eosin revealed areas of brain cell apoptosis (Figure 4). Congo red-stained slides examined under light microscopy revealed orange brown plaque-like structures (Figure 5 A) in addition to orange stained thickened wall of the cerebral blood vessels (Figure 5 B) raising the possibility of amyloid deposition. When the Congo-red stained slides examined under the polarized light, it showed birefringence both in hippocampal brain tissue (Figure $\mathbf{5} \mathbf{~ C}$ ) as well as the wall of the hippocampal blood vessels (Figure $\mathbf{5}$ D) confirming the presence of amyloid plaques.

Examination of the hippocampi of $\mathrm{AlCl}_{3}+\mathrm{Me}-$ mantine group by hematoxylin and eosin revealed more or less normal hippocampal brain tissue with normal brain cellularity and normal thickness of the hippocampal blood vessels when compared to $\mathrm{AlCl} 3$ group (Figure $6 \mathrm{~A}, \mathrm{~B}$ ). No amyloid plaques were detected neither in hematoxylin and eosin-stained slides (Figure 6 A, B) nor in Congo red-stained slides examined both under light microscopy and polarized light (Figure 7 A, B). Histopathological results similar to $\mathrm{AlCl} 3+$ Memantine group were demonstrated on examination of the hippocampi of $\mathrm{AlCl} 3+$ Clopidogrel group with no amyloid plaques detected neither in hematoxylin and eosin-stained slides (Figure $8 \mathbf{A}, \mathbf{B}$ ) nor in Congo red-stained slides when examined both under light microscopy and polarized light (Figure 9 A, B). 
Table 1: Effect of memantine $(10 \mathrm{mg} / \mathrm{kg})$ or clopidogrel $(20 \mathrm{mg} / \mathrm{kg})$ on AChE activity, tumor necrosis factor- $\alpha(T N F-\alpha)$ and interleukin-1 $\beta$ (IL-1 $\beta$ ) concentrations, and relative quantification (RQ) of amyloid precursor protein (APP) mRNA gene expression in aluminum chloride (AlC13)-treated rats $(100 \mathrm{mg} / \mathrm{kg})$.

\begin{tabular}{|c|c|c|c|c|}
\hline Groups & $\begin{array}{c}\text { Acetylcholinesterase } \\
\text { (AChE) activity } \\
\text { (U/mg tissue) }\end{array}$ & $\begin{array}{c}\text { Tumor } \\
\text { necrosis } \\
\text { factor- } \alpha \\
\text { (TNF- } \alpha \text { ) } \\
\text { concentration } \\
\text { (pg/mg tissue) }\end{array}$ & $\begin{array}{l}\text { Interleukin-1 } \beta \\
\text { (IL-1 } \beta) \\
\text { concentration } \\
\text { (pg/mg tissue) }\end{array}$ & $\begin{array}{c}\text { Relative } \\
\text { quantification } \\
\text { (RQ) of } \\
\text { amyloid } \\
\text { precursor } \\
\text { protein (APP) } \\
\text { gene } \\
\text { expression }\end{array}$ \\
\hline $\begin{array}{l}\text { Control } \\
\text { group }\end{array}$ & $0.15 \pm 0.035$ & $114.8 \pm 6.91$ & $30.34 \pm 3.14$ & $1.01 \pm 0.11$ \\
\hline $\begin{array}{l}\mathbf{A l C l}_{3} \\
\text { group }\end{array}$ & $\begin{array}{c}0.34 \pm 0.037 \\
\#\end{array}$ & $\begin{array}{l}165.1 \pm 11.18 \\
\#\end{array}$ & $\begin{array}{c}67.99 \pm 5.02 \\
\#\end{array}$ & $\begin{array}{c}2.5 \pm 0.17 \\
\#\end{array}$ \\
\hline $\begin{array}{c}\mathrm{AlCl}_{3}+\text { Memantine } \\
\text { group }\end{array}$ & $\begin{array}{c}0.25 \pm 0.032 \\
\# \$\end{array}$ & $\begin{array}{l}136.6 \pm 8.37 \\
\# \$\end{array}$ & $\begin{array}{c}50.54 \pm 7.49 \\
\# \$\end{array}$ & $\begin{array}{c}1.5 \pm 0.14 \\
\# \$\end{array}$ \\
\hline $\begin{array}{c}\mathbf{A l C l}_{3}+\text { Clopidogrel } \\
\text { group }\end{array}$ & $\begin{array}{c}0.24 \pm 0.033 \\
\# \$\end{array}$ & $\begin{array}{c}119.8 \pm 6.25 \\
\$ \&\end{array}$ & $\begin{array}{c}38.20 \pm 6.67 \\
\$ \&\end{array}$ & $\begin{array}{c}1.58 \pm 0.15 \\
\# \$\end{array}$ \\
\hline $\begin{array}{l}p \text { value of } \\
\text { ANOVA }\end{array}$ & $<0.001$ & $<0.001$ & $<0.001$ & $<0.001$ \\
\hline
\end{tabular}

Data were expressed as means $\pm \mathrm{SD}(\mathrm{n}=8)$ and were tested by one-way ANOVA followed up by Tukey post hoc test. $\mathrm{p}$ value $<0.05$ is considered to indicate statistical significance.

\section{\#: significance relative to Control group}

\$: significance relative to $\mathrm{AlCl3}$ group

\&: significance relative to $\mathrm{AlCl3}+$ Memantine group 


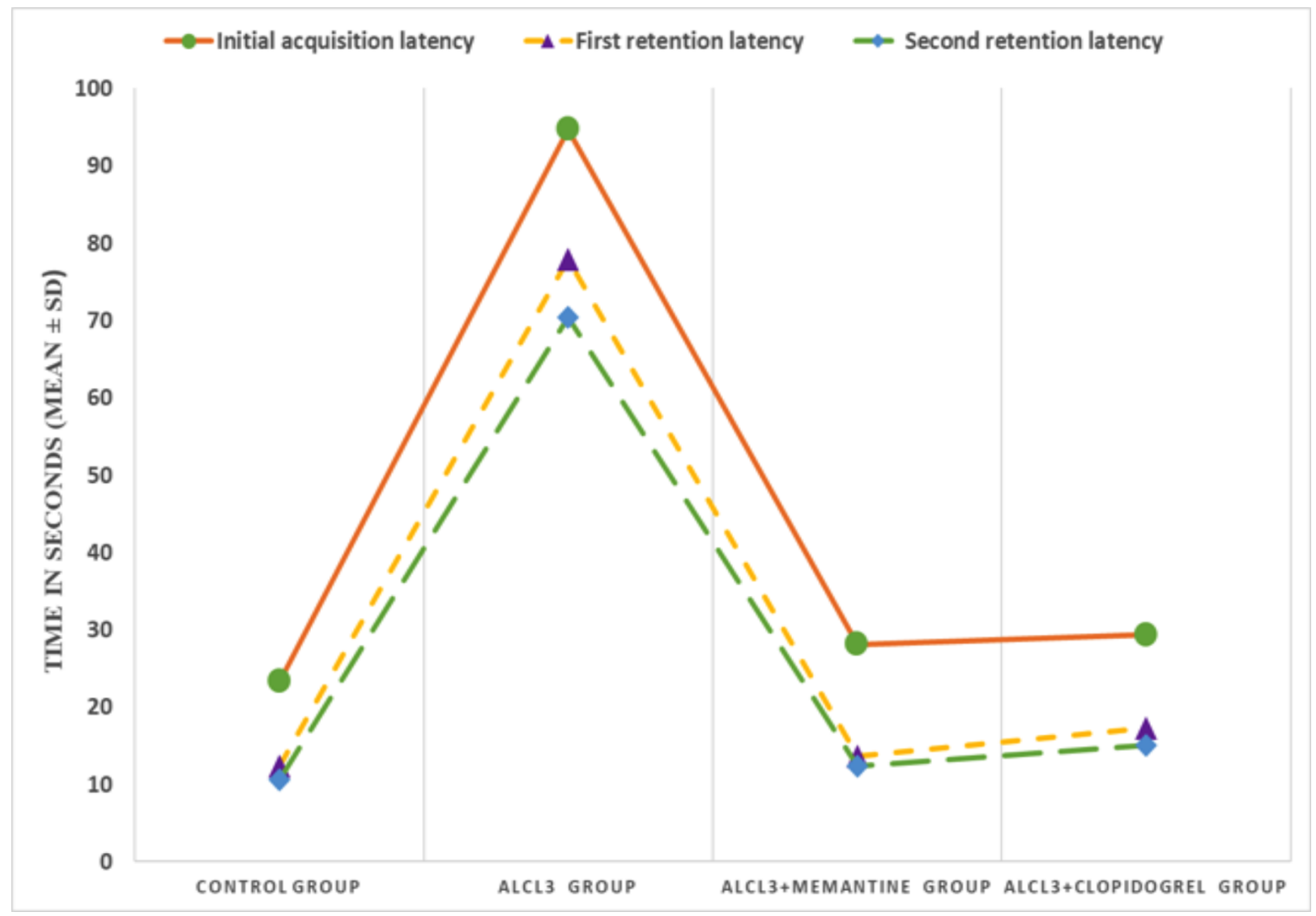

Figure (1): Effect of memantine (10 mg/kg) or clopidogrel $(20 \mathrm{mg} / \mathrm{kg})$ on memory function in Morris Water Maze (MWM) test in aluminum chloride (AlCl3)-treated rats $(100 \mathrm{mg} / \mathrm{kg})$.

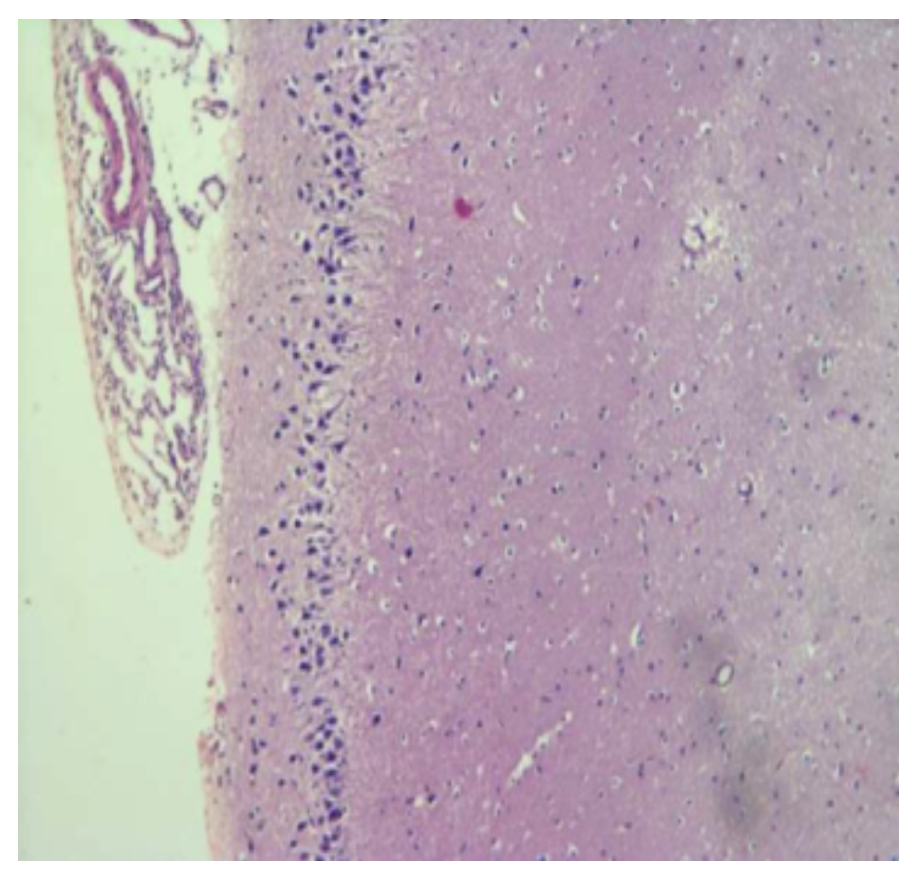

Figure (2): Hippocampus of control group stained with hematoxylin and eosin.

Control group's hematoxylin and eosin-stained section (x100) revealed normal hippocampal brain tissue with no detected microscopic abnormalities. 


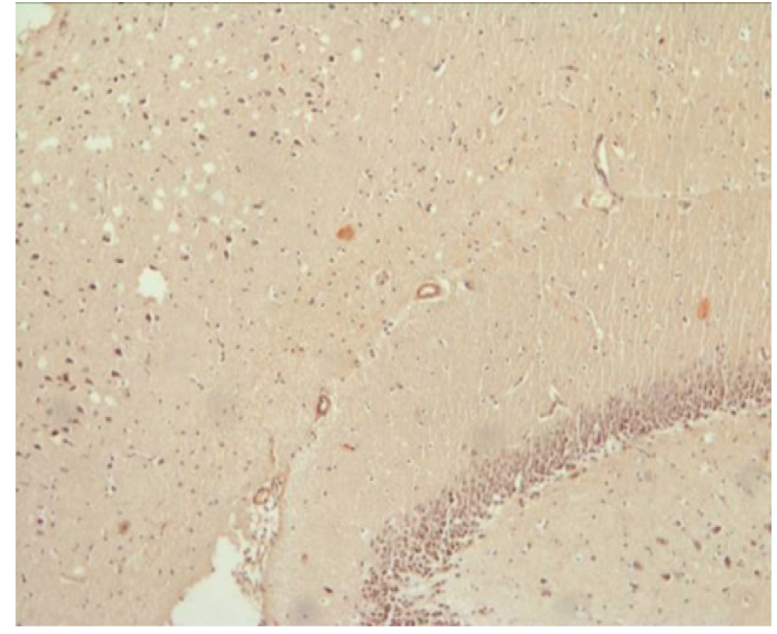

a)

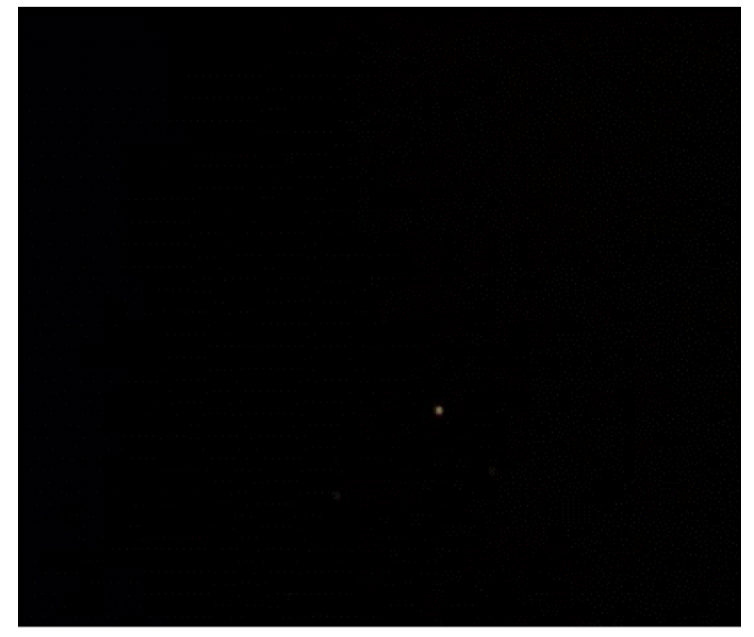

(B)

Figure 3: Hippocampus of control group stained with Congo red.

Control group's Congo red-stained sections (x100) both under light microscopy (A) and polarized light (B) revealed unremarkable pathological changes.

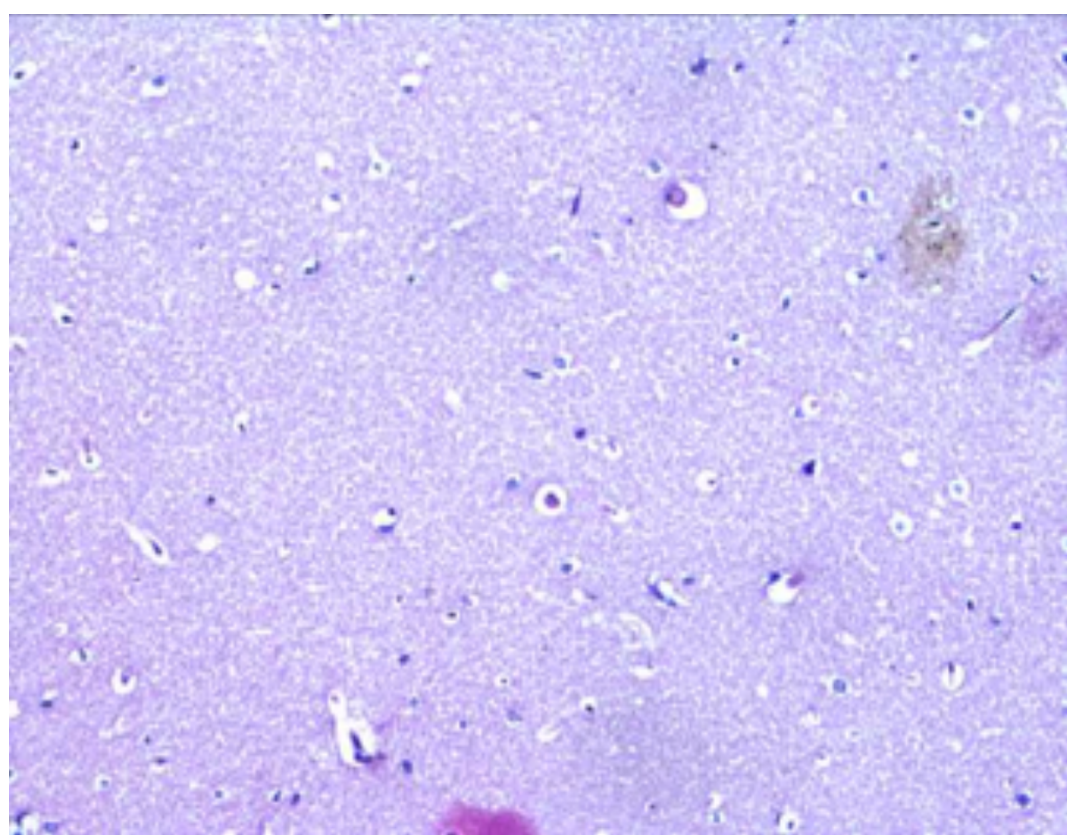

Figure 4: Hippocampus of AlCl3 group stained with hematoxylin and eosin.

$\mathrm{AlCl} 3$ group's hematoxylin and eosin-stained section (x100) revealed multiple apoptotic bodies (tip of black arrows). 


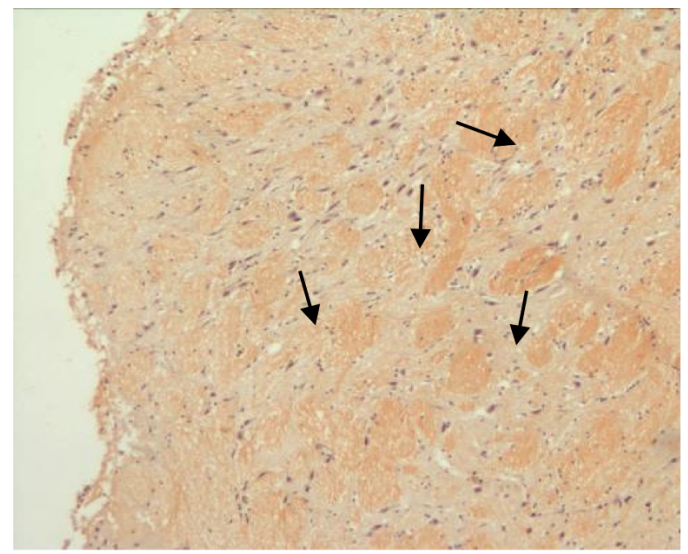

(A)

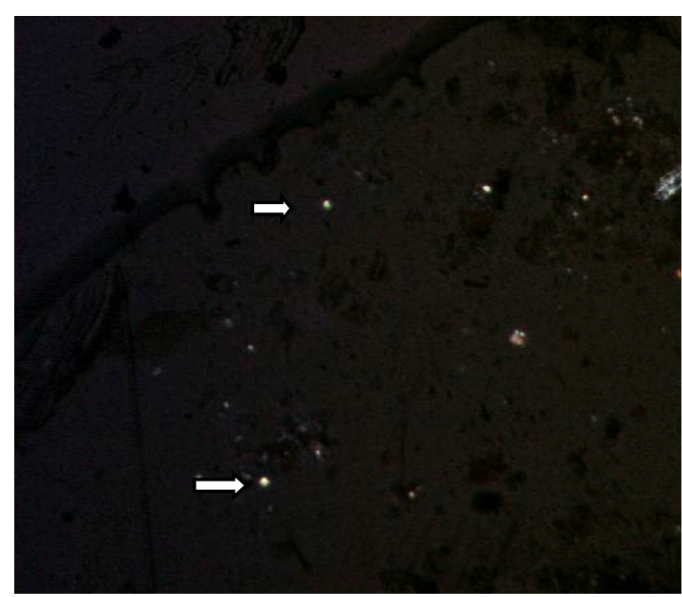

(C)

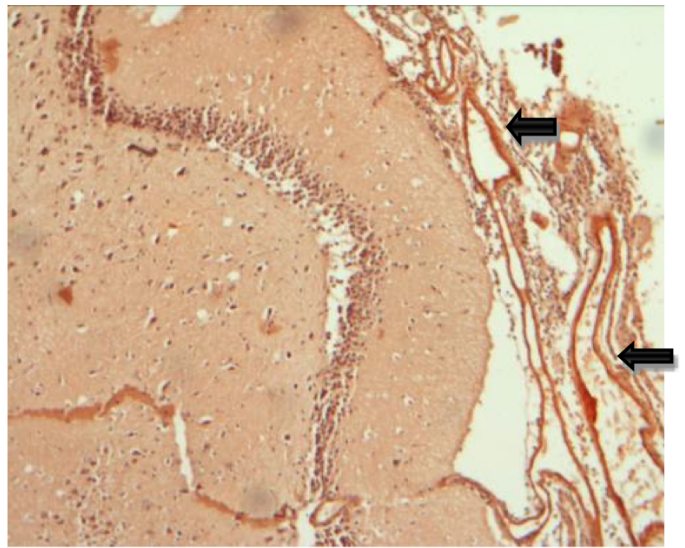

(B)

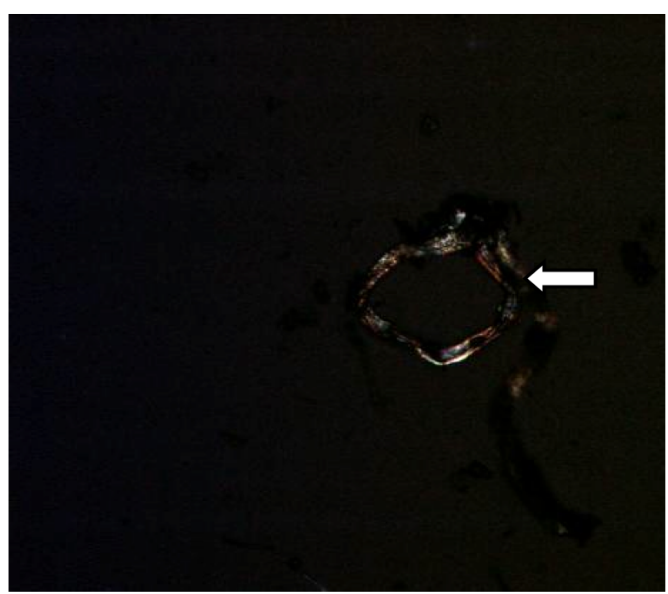

(D)

Figure 5: Hippocampus of $\mathrm{AlCl}_{3}$ group stained with Congo red.

$\mathrm{AlCl}_{3}$ group's Congo red-stained sections (x200) examined under light microscopy revealed (A) orange brown plaque-like structures (thin black arrows) within the hippocampal brain tissue; (B) orange stained thickened wall of the hippocampal blood vessels (thick black arrows). $\mathrm{AlCl}_{3}$ group's Congo red-stained sections $\mathbf{( x 2 0 0 )}$ examined under the polarized light showed (C) birefringence (white arrows) in hippocampal brain tissue and (D) the wall of the hippocampal blood vessels confirming the presence of amyloid plaques. 


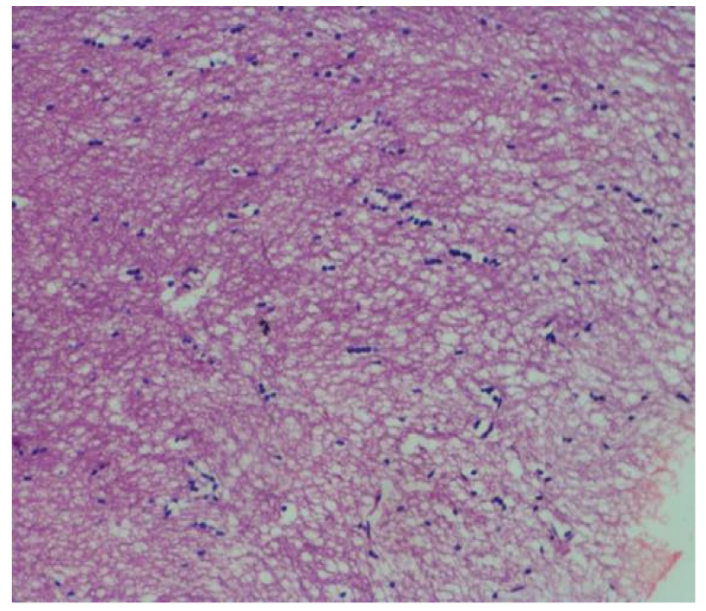

(A)

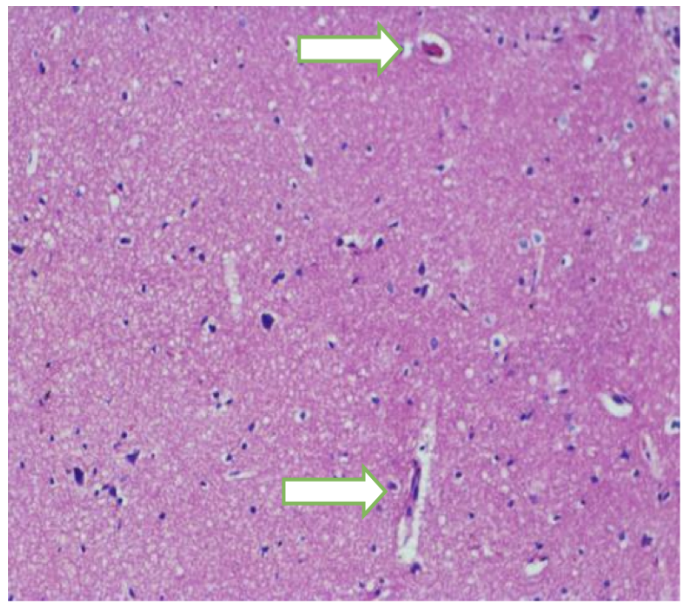

(B)

Figure 6: Hippocampus of AICl3+Memantine group stained with hematoxylin and eosin.

$\mathrm{AlCl} 3+$ Memantine group's hematoxylin and eosin-stained sections (x200) revealed (A) more or less normal hippocampal brain tissue with normal cellularity and (B) normal thickness of the blood vessels (white arrows). No amyloid plaques were detected.

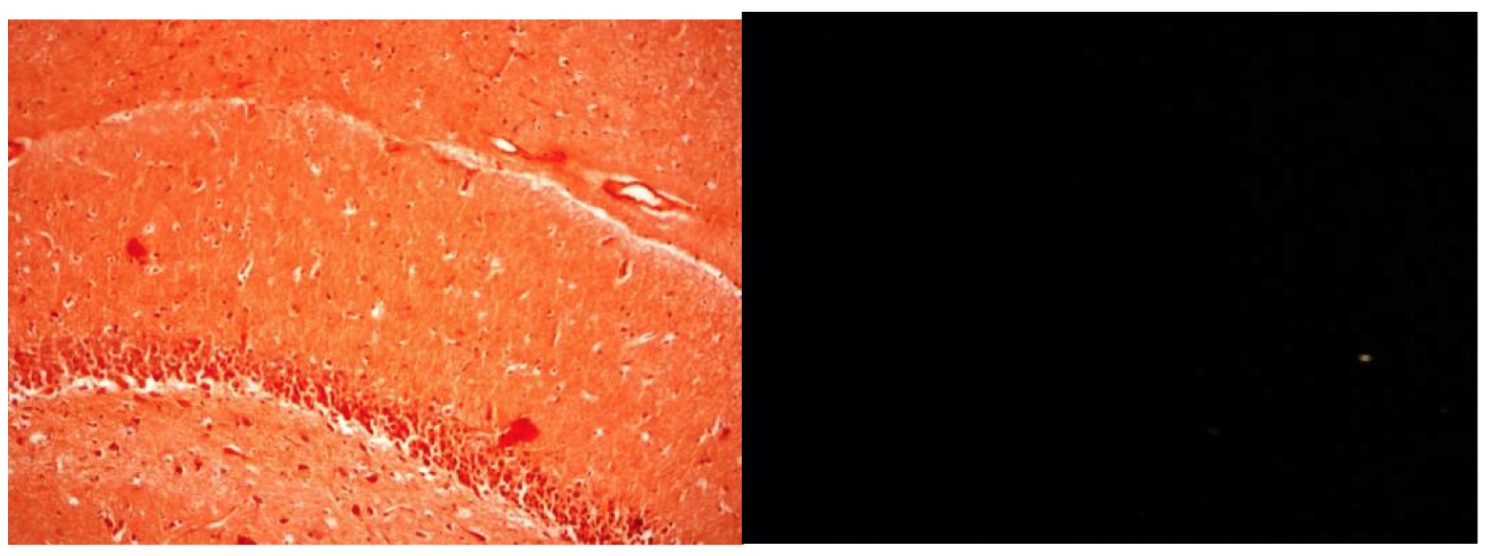

(A)

(B)

Figure 7: Hippocampus of AlCl3+Memantine group stained with Congo red.

AlCl3+Memantine group's Congo red-stained sections (x200) revealed absent amyloid plaques when examined (A) under light microscopy and (B) polarized light. 


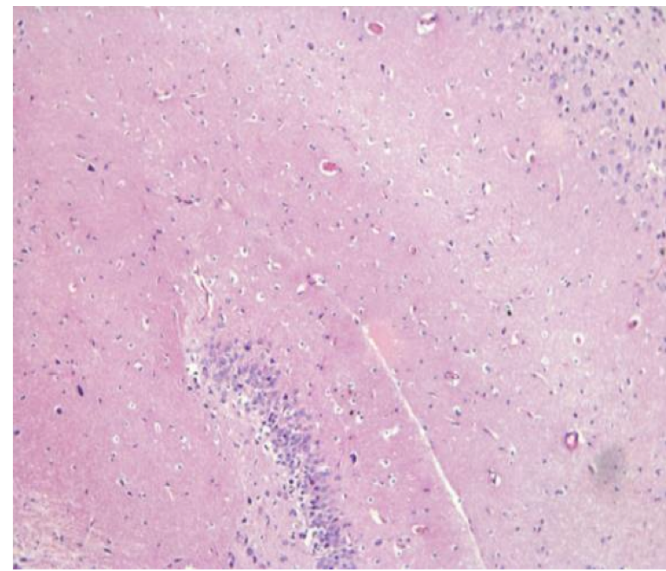

(A)

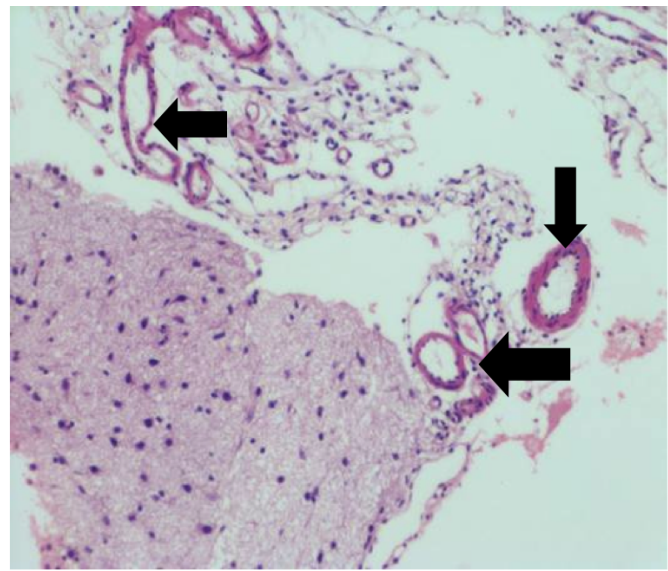

(B)

Figure 8: Hippocampus of AICl3+Clopidogrel group stained with hematoxylin and eosin.

$\mathrm{AlCl} 3+\mathrm{Clopidogrel}$ group's hematoxylin and eosin-stained sections (A, x100 and B, x200) revealed (A) more or less normal hippocampal brain tissue with normal cellularity and (B) normal thickness of the blood vessels (black arrows). No amyloid plaques were detected.

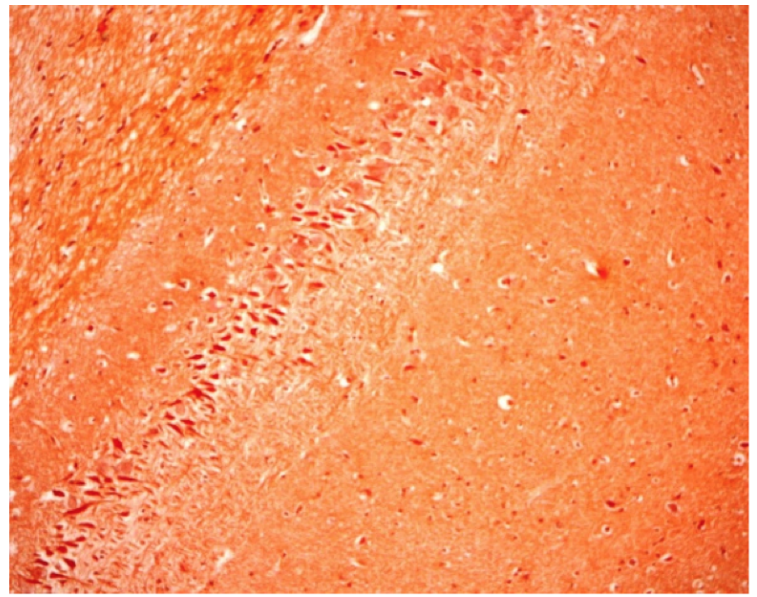

(A)

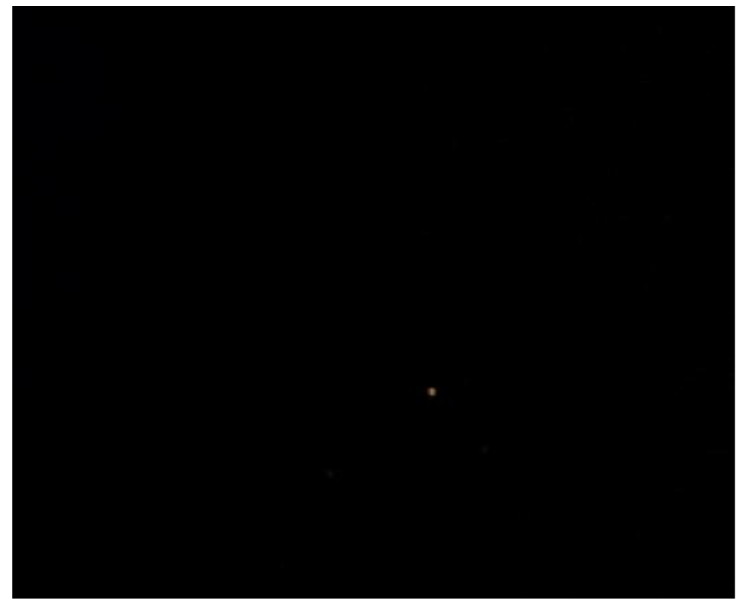

(B)

Figure 9: Hippocampus of AlCl3+Clopidogrel group stained with Congo red.

$\mathrm{AlCl} 3+\mathrm{Clopidogrel}$ group's Congo red-stained slides (x200) revealed absent amyloid plaques when examined (A) under light microscopy and (B) polarized light. 


\section{Discussion}

The current study's results demonstrated that continuous $\mathrm{AlCl} 3$ administration in rats for 42 days led to spatial learning and memory impairment as assessed by MWM. AICl3-treated rats showed a significant prolongation in time taken to jump onto the platform in both maze acquisition and retention phases compared to control rats. These results are in consistent with earlier experimental studies that demonstrated cognitive deficits caused by the chronic $\mathrm{AlCl} 3$ administration in rats (Qusti, 2017; Rather et al, 2018), and mice (Jangra et al, 2015; Kasbea et al, 2015). Cognitive decline after aluminum (Al3+) exposure may be caused by numerous $\mathrm{Al} 3+$ actions on the nerve cells. Exposure to $\mathrm{Al} 3+$ can result in a dramatic accumulation of $\mathrm{Al} 3+$ in the brain leading to a severe impairment in learning and memory abilities and in long term potentiation (LTP) in the hippocampus (Liang et al, 2012). This impairment is caused by $\mathrm{Al} 3+$ capacity to inhibit downstream effector mediators e.g. cyclic guanosine monophosphate (cGMP) participating in LTP and disrupt the glutamate-nitric oxide-cGMP pathway in the rat brain (Canales et al, 2001).

In contrast, co -administration of memantine or clopidogrel with $\mathrm{AlCl} 3$ for 42 days to rats significantly improved spatial learning and memory deficits as shown by a significant decline in the MWM test's $1^{\text {st }}$ and $2^{\text {nd }}$ RLs compared to AICl3-treated rats.

Previous studies also supported that memantine improved memory and cognition assessed by MWM test (Abdel-Aal et al, 2011; Ahmed et al, 2014). Memantine could prevent Al3+-induced neuronal toxicity and cognitive deficit by several mechanisms. Memantine unexpectedly is a more potent blocker when glutamate levels rise due to its low affinity and non-competitive antagonism for NMDA receptor, so causing memantine to favora- bly decrease pathological NMDA receptor stimulation without disrupting the physiological activity important for cognition (Lockrowa et al, 2011). Memantine also decreased elevated AChE enzyme activity (Ahmed et al, 2014; Al-Bishri et al, 2017). Moreover, memantine prevent cognitive deficits induced by neuroinflammation (Rosi et al, 2009) and enhanced cognitive functions in $A \beta$ induced $A D$ in rats (Nyakas et al, 2010). In the current study, memantine significantly decreased hippocampal AChE activity, TNF- $\alpha$ and IL-1 $1 \beta$ concentrations, APP mRNA gene expression and $A \beta$ deposition.

To our knowledge, this is the initial study to test clopidogrel neuroprotective influence on $\mathrm{AlCl}_{3}$-triggered $\mathrm{AD}$ in rats. Clopidogrel cognitive enhancing effect might be due to its ability to decrease AChE activity and hence improving cholinergic neurotransmission as shown in the current study. Other mechanisms for cognitive enhancement produced by clopidogrel might be due to its ameliorating effect on inflammation by significantly decreased hippocampal TNF- $\alpha$, IL- $1 \beta$ levels or its lowering effect on APP mRNA gene expression and $A \beta$ as shown in the current study. Several previous studies demonstrated an antiinflammatory effect of clopidogrel in different animal models (Patel et al, 2012; Webster et al, 2013; Suh et al, 2016).

In the current study, $\mathrm{AlCl}_{3}$-treated group exhibited a significant elevation of AChE activity in the hippocampus as compared to control rats. Information about the AChE activity alteration in $A D$ animal models are not constant, with some showing elevated, and others showing suppressed activity. These divergences may be caused by the variations in animal models and experimental methods, involving timing of sample taking for assessing activity (Xiao et al, 2011). In consistency with our results, previous studies reported increased $\mathrm{AChE}$ activity with $\mathrm{AICl}_{3}$-treated rats (Lin 
et al, 2015; Prema et al, 2016; Qusti, 2017; Rather et al, 2018). The increased AChE activity in AlCl3-treated rats might be caused by direct $\mathrm{Al} 3+-$ induced neuronal toxicity. Prolonged $\mathrm{Al} 3+$ administration changes AChE kinetics and its elevated activity may be attributed to $\mathrm{Al}^{3+}$ ability to allosterically interact with the enzyme peripheral anionic site, causing modification of its secondary structure, thereby enhancing its activity (Gulya et al., 1990; Zatta et al, 1994). Another possible mechanism for increased AChE is due to IL-1 $\beta$ overproduction as shown in the current study that promotes the activity and expression of AChE via interaction of IL-1 $\beta$ with muscarinic acetylcholine receptors (AChRs) (Schliebs et al, 2006). Additional explanation might be due to $A \beta$ deposition as shown in the current study. $A \beta$ combines with nicotinic AChRs causing enhanced AChE activity (Arendt et al, 1984).

Contrarily, other studies reported that $\mathrm{AICl}_{3}$ administration inhibited AChE activity compared to control groups (Lakshmi et al, 2014; Lakshmi et al, 2015; Taïr et al, 2016; Singla \& Dhawan, 2017). The reduction in AChE activity may be attributed to $\mathrm{Al} 3+$ attachment to $\mathrm{SH}$-groups of $\mathrm{AChE}$ catalytic active site, which ultimately have hindered the activity of enzyme in various chemical reactions (Singla \& Dhawan, 2017).

Co-administration of memantine or clopidogrel with $\mathrm{AlCl} 3$ to rats results in significant decrease of hippocampal AChE activity compared to AICl3treated rats. Memantine had shown to decrease AChE activity in several studies (Ahmed et al, 2014; Al-Bishri et al, 2017). The decreased AChE activity with mamantine might be due to ability of memantine to lower IL-1 $\beta$ concentration or APP mRNA gene expression and $A \beta$ deposition as shown in the current study. This study is the first study to show clopidogrel inhibitory effect on AChE activity in $\mathrm{AlCl}_{3}$ - induced $\mathrm{AD}$ model. Similarly, the decreased AChE activity with clopidogrel might be due to its ability to lower IL-1 $\beta$ concentration, APP mRNA gene expression and/or A $\beta$ deposition as shown in the current study.

The current study's results demonstrated that continuous $\mathrm{AlCl}_{3}$ administration in rats significantly elevated hippocampal TNF- $\alpha$, IL-1 $\beta$ concentrations compared to control rats. These data are consistent with other studies in rats (Cao et al, 2016; Qusti, 2017; Rather et al, 2018; Ravi et al, 2018) and mice (Jangra et al, 2015; Kasbea et al, 2015). In humans, brains and plasma of $A D$ patients showed elevated TNF- $\alpha$ concentrations (Chang et al, 2017). Similarly, IL-1 $\beta$ was elevated in both the brains (Cacabelos et al, 1994) and plasma of $A D$ patients (Forlenza et al, 2009).

Aluminum is strongly implicated in neuroinflammation induction and inflammatory cytokine production (Cao et al, 2016). $\mathrm{Al}^{3+}$ can activate the glial cells and initiate the macrophages responsiveness (Campbell et al, 2002). Microglial stimulation by $\mathrm{Al}^{3+}$ leads to marked proinflammatory cytokine generation e.g. TNF- $\alpha$, IL-1 $\beta$, IL-6 (Cao et al, 2016). Moreover, Al3+ activates the transcription factor nuclear factor-kappa B (NF$\kappa B)$, mitogen-activated protein kinase/activator protein-1, and hypoxia inducible factor-1 (HIF-1), which are implicated in inflammation (Lukiw et al, 2005; Verstraeten et al, 2008). In addition, accumulation of $\mathrm{Al}^{3+}$ in the hippocampus causes abnormal deposition of $A \beta$ (Wang et al, 2014) which induces microglial chemotaxis and provide a chronic stimulus to microglial cells contributing to the ongoing inflammatory process (Lue et al, 2001). Also, $A \beta$ itself may act as an inflammation inducing factor leading to stimulation of several inflammatory components (Ghavami et al, 2014).

Additional underlying mechanism for increased hippocampal TNF- $\alpha$ and IL-1 $\beta$ concentrations by chronic $\mathrm{AlCl} 3$ administration is $\mathrm{Al}^{3+}{ }_{\text {-induced excit- }}$ otoxicity. Continued $\mathrm{Al}^{3+}$ administration was 
shown to elevate brain glutamate concentration (Abdel-Zaher et al, 2017). Functional ionotropic glutamate receptors such as NMDA receptors in the microglia respond to glutamate release during synaptic activity or damage leading to inflammatory cytokine liberation such as TNF- $\alpha$ and IL-1 $\beta$ (Domercq et al, 2013).

In contrast, the current study revealed that coadministration of memantine or clopidogrel with $\mathrm{AICl} 3$ to rats resulted in significant decrease of hippocampal TNF- $\alpha$, IL-I $\beta$ concentrations compared to $\mathrm{AlCl} 3$-treated rats. In addition, the decrease of hippocampal TNF- $\alpha$, IL- $1 \alpha$ concentrations by clopidogrel was significant compared to its decrease by memantine.

Several studies using memantine reported similar results in $\mathrm{AlCl}_{3}$ induced model (Alawdi et al, 2017) and in other $A D$ animal models (Hemmati et al, 2013; Rai et al, 2013; Susmita et al, 2016; Budni et al, 2017). Memantine was also shown to possess anti-inflammatory effects in vitro in microglia and astrocytes (Wu et al, 2009) and in T cells (Kahlfub et al, 2014), and in vivo against morphine addictive behavior in rats (Chen et al, 2013), and lipopolysaccharide (LPS)- induced acute lung injury in mice (Ma et al, 2014). Also, it was shown that memantine possess antiinflammatory effects in clinical trials of bipolar depression (Lee et al, 2014).

One explanation for decreased hippocampal TNF- $\alpha$ and IL-1 $\beta$ concentrations by memantine administration is due to its ability to inhibit NF-KB pathway as shown in several studies in $\mathrm{AICl} 3-$ induced AD model (Ahmed et al, 2014; Alawdi et al, 2017). Another explanation is due to ability of memantine to activate cholinergic antiinflammatory pathway by its inhibitory effect on AChE activity leading to increased acetylcholine (ACh) level. ACh is capable of suppression of the inflammatory cytokine liberation such as TNF- $\alpha$ and IL-1 $\beta$ (Shytle et al, 2004). Also, decreased hippocampal TNF- $\alpha$ and IL-1 $\beta$ concentrations by memantine might be due to its lowering effect on APP mRNA gene expression and $A \beta$ as shown in the current study. Additional possible mechanism might be due to its ability to block NMDA receptor and halt $\mathrm{Al}^{3+}$-induced excitotoxicity and glutamate release (Abdel-Zaher et al, 2017).

This is the initial study to demonstrate inflammation ameliorating influence of clopidogrel in $\mathrm{AlCl}_{3}$-induced AD model. Several studies showed inflammation ameliorating influence of clopidogrel in global cerebral ischemia (Webster et al, 2013) and other models of LPS-induced inflammation (Hagiwara et al, 2011), atherosclerosis (Hadi et al, 2013), renal injury (Tu et al, 2008), inflammatory bowel disease (IBD) (Patel et al, 2012), and asthma (Suh et al, 2016). Molecular explanation for decreased hippocampal TNF- $\alpha$ and IL-1 $\beta$ concentrations by clopidogrel administration could be due to its ability to inhibit NF-KB pathway as shown in a previous study of bilateral common carotid artery occlusion (global cerebral ischemia) where clopidogrel treatment decreases NF-kB expression in hippocampal CA1 neuron and improved its viability and decreased immune responses (Webster et al, 2013). Another explanation is due to its ability to activate cholinergic anti-inflammatory pathway by its inhibitory effect on AChE activity as shown in the current study leading to increased ACh level. Also, decreased hippocampal TNF- $\alpha$ and IL- $1 \beta$ concentrations by clopidogrel might be due to its lowering effect on APP mRNA gene expression and $A \beta$ as shown in the current study.

Additional explanation for decreased hippocampal TNF- $\alpha$ and IL-1 $\beta$ concentrations by clopidogrel is due to its ability to block $\mathrm{P}_{2} \mathrm{Y}_{12}$ receptors on the microglia leading to inhibition of microglial chemotaxis and consequently microglial phagocytosis. Chemokines and nucleotide adenosine tri- 
phosphate (ATP) manage proper microglial migration to destructed region (Noda \& Suzumura, 2012). Induction of apoptosis and necrosis by $\mathrm{Al} 3+$ was previously reported in rats and mice (Prakash \& Sudhandiran, 2015; Said \& Abd Rabo, 2017). Apoptosis and necrosis of neurons in AD result in release of ATP (Glass et al, 2010) which induces microglial migration (chemotaxis) through $\mathrm{P} 2 \mathrm{Y}$ receptors, especially $\mathrm{P}_{2} \mathrm{Y}_{12}$ (Noda \& Suzumura, 2012). $P_{2} Y_{12}$ receptor is solely present in microglia in the central nervous system, is not present in peripheral macrophages and so, is a reliable marker to differentiate inhabitant microglia from penetrated macrophages (Tronel et al, 2017). The initial chemotaxis of microglial cells serves as a precursor to subsequent microglial activation and functional responses such as phagocytosis; however, chemotactic responses are also ongoing and could contribute to neuronal degeneration in environments of chronic neuroinflammation in brain and in the progression of disease (McLarnon, 2012).

Also, a unique explanation for decreased hippocampal TNF- $\alpha$ and IL- $1 \beta$ concentrations by clopidogrel administration is due to its antiplatelet effect. A number of studies demonstrated that platelet activation is strongly linked to inflammation, and platelet activation can stimulate or exacerbate inflammation in vivo (Weyrich et al, 2003; Gawaz et al, 2005; Patel et al, 2012). Clopidogrel can suppress platelet activation by $\mathrm{P}_{2} \mathrm{Y}_{12}$ receptor blockade (Tu et al, 2008). Several studies showed that clopidogrel reduced inflammation by its antiplatelet effect in various animal models (Evangelista et al, 2005; Angiolillo et al, 2006; Tu et al, 2008; Patel et al, 2012).

The current study's results demonstrated that continuous $\mathrm{AlCl}_{3}$ administration in rats significantly increased mRNA expression of APP gene compared to control rats. Earlier studies have demonstrated parallel results with increased mRNA expression (Khalaj et al, 2016; Yang et al, 2016) and protein expression of APP gene (Thenmozhi et al, 2016; Singla \& Dhawan, 2017; Rather et al, 2018) in $\mathrm{AlCl}_{3}$-treated rats compared to control rats. Explanation for increased mRNA expression of APP gene is that the APP gene promoter region has numerous binding sites selective for NF-KB and HIF-1; two transcription factors linked to stress. They are implicated together in AD pathophysiology and pathology and are triggered by $\mathrm{Al}^{3+}$ (Lukiw et al, 2005). It was also reported that IL-1 enhance APP promoter transcriptional function (Lahiri and Nall, 1995). In addition, IL-1 significantly enhance APP mRNA translation (Rogers et al, 1999). Moreover, IL-1 (IL-1 $\alpha$ and IL-1 $\beta$ ) and TNF- $\alpha 1$ upregulate A $\beta P P$ transcription and translation in the astrocytic cells via regulatory elements present in the A $\beta P P$ promoter and in $5^{\prime}-$ UTR, respectively (Lahiri et al, 2003).

Co-administration of memantine with $\mathrm{AICl} 3$ in rats significantly decreased mRNA expression of APP gene compared to AlCl3-treated rats. Previous studies showed similar results with decreased protein expression of APP by memantine through inhibiting internal ribosomal entry site (Wu \& Chen, 2009; Tasi et al, 2015) Other studies showed that memantine therapy decreased the membrane-bound APP entire cortical concentrations $(45 \%-55 \%)$ in transgenic and nontransgenic mice (Unger et al, 2006). An explanation for the decreased APP mRNA gene expression by memantine is due to its ability to lower TNF- $\alpha$ and IL- $1 \beta$ concentrations as shown in the current study. Moreover, APP is produced by glutamate releasing nerve cells (Ouimet et al, 1994); so, NMDA receptor antagonism by memantine may affect the total APP formation (Unger et al, 2006). NF-кB enhanced APP promoter transcriptional function in glutamate-treated neurons (Grilli et al, 1996).

In the current study, concomitant clopidogrel 
treatment with $A I C l 3$ in rats significantly decreased mRNA expression of APP gene compared to AICl3-treated rats. An explanation for decreased mRNA expression of APP gene by clopidogrel is due to its ability to lower TNF- $\alpha$ and IL-1 $\beta$ concentrations as shown in the current study.

All the current study's results were confirmed by histopathological examination of the hippocampi from different rat groups stained with hematoxylin and eosin and Congo red stains. Examination of hippocampal tissue of $\mathrm{AlCl} 3$ treated rats stained with hematoxylin and eosin revealed amyloid plaques and degenerative changes compared to control rats. Similar earlier studies had shown similar results of amyloid plaques in $\mathrm{AlCl}_{3}$ model of AD (Lin et al, 2015; Ali et al, 2016; Babu et al, 2016; Singh et al, 2018). Congo red-stained hippocampal tissue examined both under light microscopy and polarized light confirmed the presence of amyloid plaques. These results are consistent with earlier studies (Balgoon et al, 2015; Kaur \& Sodhi, 2015; Abdel-Salam et al, 2016).

Examination of hippocampal tissue of rats concomitantly treated with $\mathrm{AICl} 3$ and memantine stained with hematoxylin and eosin revealed more or less normal hippocampal brain tissue when compared to AlCl3-treated rats. In addition, no amyloid plaques were detected. These results are in accordance with earlier studies that showed memantine lowering effect on amyloid plaques (Ahmed et al, 2014; Babu et al, 2016; Alawdi et al, 2017; Al-Bishri et al, 2017). Congo red stain of hippocampal tissue examined both under light microscopy and polarized light confirm the absence of amyloid plaques. These results are in consistent with earlier studies utilized memantine in other AD models (Sil et al, 2016).

Examination of hippocampal tissue of rats concomitantly treated with $\mathrm{AICl} 3$ and clopidogrel 2018 Mansoura Medical Journal stained with hematoxylin and eosin stain or Congo red stain showed similar results to $\mathrm{AlCl}_{3}$ and memantine co-treated rats. To our knowledge, this study is the initial one to show clopidogrel potential neuroprotective influence on histopathology in an $\mathrm{AlCl}_{3}$-triggered $\mathrm{AD}$ model.

Histopathological changes in hippocampus in different rat groups may be explained by the biochemical and transcriptional gene expression changes which are previously discussed.

\section{Conclusion}

The current study highlighted that clopidogrel improves behavioral and biochemical function in AICl3-treated rat brain, an effect that could be explained mainly by its anti-inflammatory properties. Clinical studies are required to evaluate the potential neuroprotective effect of clopidogrel in $A D$ patients.

\section{References}

1. Abdel-Aal RA, Assi $A A$, and Kostandy BB (2011): Memantine prevents aluminuminduced cognitive deficit in rats. Behavioural Brain Research, 225:31-38.

2. Abdel-Salam OM, Hamdy SM, Seadawy, SAM, Galal AF, Abouelfadl DM and Atrees SS (2016): Effect of piracetam, vincamine, vinpocetine, and donepezil on oxidative stress and neurodegeneration induced by aluminum chloride in rats. Comparative Clinical Pathology, 25(2):305-318.

3. Abdel-Zaher AO, Hamdy MM, Abdel-Rahman MS and Abd El-hamid DH (2017): Protective effect of citicoline against aluminum-induced cognitive impairments in rats. Toxicology and Industrial Health, 33(4):308-317.

4. Ahmed HH, Zaazaab AM, and Abd El-Motelp BA (2014): Zingiber officinale and Alzheimer's 
Disease: Evidences and Mechanisms. Int. J. Pharm. Sci. Rev. Res., 27(2):142-152.

5. Alawdi SH, El-Denshary ES, Safar MM, Eidi H, David MO and Abdel-Wahhab MA (2017): Neuroprotective Effect of Nanodiamond in Alzheimer's Disease Rat Model: a Pivotal Role for Modulating NF-?B and STAT3 Signaling. Mol Neurobiol, 54:1906-1918.

6. Al-Bishri WM, Hamza $\mathrm{AH}$, and Farran SK (2017): Resveratrol Treatment Attenuates Amyloid Beta, Tau Protein and Markers of Oxidative Stress, and Inflammation in Alzheimer's disease Rat Model. International Journal of Pharmaceutical Research \&Allied Sciences, 6 (3):71-78.

7. Albus U (2012): Guide for the Care and Use of Laboratory Animals (8th edn). Laboratory Animals, 46:267-268.

8. Ali AA, Ahmed $\mathrm{HI}$, and Abu-Elfotuh $\mathrm{K}$ (2016): Modeling Stages Mimic Alzheimer's Disease Induced by Different Doses of Aluminum in Rats: Focus on Progression of the Disease in Response to Time. J Alzheimers Parkinsonism Dementia, 1(1):002.

9. Angiolillo DJ, Fernandez-Ortiz A, Bernardo E, Ramirez C, Sabate M, Jimenez-Quevedo $P$, et al (2006): Clopidogrel withdrawal is associated with proinflammatory and prothrombotic effects in patients with diabetes and coronary artery disease. Diabetes, 55:780-784.

10. Arendt $\mathrm{T}$, Bigl $\mathrm{V}$, Tennstedt $\mathrm{A}$, and Arendt $\mathrm{A}$ (1984): Correlation between cortical plaque count and neuronal loss in the nucleus basalis in Alzheimer's disease. Neurosci Lett, 48:81-5

11. Babu SM, Swain S, and Boyapati P (2016): Neuroprotective activity of ethanolic extract of
Tamarindus indica seeds against aluminium induced neurotoxicity. Asian J.Pharm.Hea.Sci., $6(2)$.

12. Balgoon MJ, Raouf GA, Qusti SY, and Ali SS (2015): ATR-IR Study of the Mechanism of Aluminum Chloride Induced Alzheimer's Disease; Curative and Protective Effect of Lipidium sativum Water Extract on Hippocampus Rats Brain Tissue. International Journal of Medical, Health, Biomedical, Bioengineering and Pharmaceutical Engineering, 9 (11).

13. Budni J, Feijó DP, Batista-Silva H, Garcez ML, Mina F, Belletini-Santos T, et al (2017): Lithium and memantine improve spatial memory impairment and neuroinflammation induced by b-amyloid 1-42 oligomers in rats. Neurobiology of Learning and Memory, 141:84-92.

14. Cacabelos R, Alvarez XA, Fernández-Novoa $\mathrm{L}$, Franco $\mathrm{A}$, Mangues $\mathrm{R}$, Pellicer $\mathrm{A}$, et al (1994): Brain interleukin-1 beta in Alzheimer's disease and vascular dementia. Methods Find Exp Clin Pharmacol., 16(2):141-51.

15. Campbell A, Yang EY, Tsai-Turton $M$, and Bondy SC (2002): Proinflammatory effects of aluminium in human glioblastoma cells. Brain Res, 933:60-65.

16. Canales JJ, Corbalan R, Montoliu C, Llansola M, Monfort P, Erceg S, et al (2001): Aluminium impairs the glutamate-nitric oxide-cGMP pathway in cultured neurons and in rat brain in vivo: molecular mechanisms and implications for neuropathology. J Inorgan Biochem, 87:63-9.

17. Cao Z, Yang $X$, Zhang $H$, Wang $H$, Huang $W, X u F$, et al (2016): Aluminum chloride induces neuroinflammation, loss of neuronal dendritic spine and cognition impairment in developing rat. Chemosphere, 151:289-295. 
18. Carleton HM, Drury RAB and Wallington EA (1980): Carleton's histological technique, 5th ed. Oxford: Oxford University Press, 1980:188-291.

19. Chang R, Yee K-L, and Sumbria RK (2017): Tumor necrosis factor ? Inhibition for Alzheimer's Disease. J Cent Nervous Syst Dis, 9 (2017).

20. Chen M, Du Z-Y, Zheng X, Li D-L, Zhou R$P$, and Zhan K (2018): Use of curcumin in diagnosis, prevention, and treatment of Alzheimer's disease. Neural Regen Res., 13(4):742752.

21. Chen S-L, Tao P-L, Chu C-H, Chen S-H, Wu H-E, Tseng LF, et al (2013): Low-dose memantine attenuated morphine addictive behavior through its anti-inflammation and neurotrophic effects in rats. Journal of Neuroimmune Pharmacology, 7:444-453.

22. Deardorff WJ and Grossberg GT (2016): A fixed-dose combination of memantine extended-release and donepezil in the treatment of moderate-to-severe Alzheimer's disease. Drug Design, Development and Therapy, 10:3267-3279.

23. Domercq $\mathrm{M}$, Vázquez-Villoldo $\mathrm{N}$, and Matute $C$ (2013): Neurotransmitter signaling in the pathophysiology of microglia. Front Cell Neurosci., 7: 49.

24. Du X, Wang X and Geng M (2018): Alzheimer's disease hypothesis and related therapies. Translational Neurodegeneration, 7:2.

25. Evangelista $\mathrm{V}$, Manarini S, Dell'Elba G, Martelli N, Napoleone E, Di Santo A, et al (2005): Clopidogrel inhibits platelet-leukocyte adhesion and platelet dependent leukocyte activation. Thromb Haemost, 94:568-577.
26. Forlenza OV, Diniz BS, Talib LL, Mendonca VA, Ojopi EB, Gattaz WE, et al (2009): Increased serum IL-1B level in Alzheimer's disease and mild cognitive impairment. Dement Geriatr Cogn Disord, 28:507-512.

27. Gawaz M, Langer $\mathrm{H}$, and May AE (2005): Platelets in inflammation and atherogenesis. $J$ Clin Invest, 115: 3378-3384.

28. Ghavami S, Shojaei S, Yeganeh B, Ande SR, Jangamreddy JR, Mehrpourg $M$, et al (2014): Autophagy and apoptosis dysfunction in neurodegenerative disorders. Progress in Neurobiology, 112:24-49.

29. Glass CK, Saijo K, Winner B, Marchetto MC, and Gage FH (2010): Mechanisms Underlying Inflammation in Neurodegeneration. Cell, 140 (6): 918-934

30. Grilli M, Goffi F, Memo M, and Spano P (1996): Interleukin-1beta and glutamate activate the NF-kappaB/Rel binding site from the regulatory region of the amyloid precursor protein gene in primary neuronal cultures. $\mathrm{J}$ Biol Chem., 271:15002-15007.

31. Gulya K, Rakonczay Z, and Kasa P (1990): Cholinotoxic effects of aluminium in rat brain. $J$ Neurochem, 54:1020-1026.

32. Guo HB, Cheng YF, Wu JG, Wang CM, Wang HT, Zhang C, et al (2015): Donepezil improves learning and memory deficits in APP/ PS1 mice by inhibition of microglial activation. Neuroscience, 290:530-42.

33. Hadi NR, Mohammad BI, Ajeena IM, and Sahib HH (2013): Anti-atherosclerotic Potential of Clopidogrel: Antioxidant and AntiInflammatory Approaches. BioMed Research International, 2013:790263. 
34. Hagiwara S, Iwasaka H, Hasegawa A, Oyama M, Imatomi R, Uchida $T$, et al (2011): Adenosine diphosphate receptor antagonist clopidogrel sulfate attenuates LPS-induced systemic inflammation in a rat model. Shock, 35: 289-292.

35. Hemmati F, Dargahi L, Nasoohi S, Omidbakhsh R, Mohamed Z, Chik Z, et al (2013): Neurorestorative effect of FTY720 in a rat model of Alzheimer's disease: Comparison with Memantine. Behavioural Brain Research, 252:415- 421.

36. IACUC Guidelines: Anesthesia. The university of Lowa, Office of Animal Resources, Institutional Animal Care and Use Committee [WWW Document], 2017. URL https:// animal.research.uiowa.edu/iacuc-guidelinesanesthesia.

37. Jangra A, Kasbe P, Pandey SN, Dwivedi S, Gurjar SS, Kwatra M, et al (2015): Hesperidin and Silibinin Ameliorate Aluminum-Induced Neurotoxicity: Modulation of Antioxidants and Inflammatory Cytokines Level in Mice Hippocampus. Biol Trace Elem Res, 168:462-471.

38. Kahlfuß S, Simma N, Mankiewicz J, Bose T, Lowinus T, Klein-Hessling S, et al (2014): Immunosuppression by $\mathrm{N}$ Methyl-D-Aspartate receptor antagonists is mediated through inhibition of Kv1.3 and KCa3.1 channels in T cells. Molecular and Cellular Biology, 34:820-831.

39. Kasbea $P$, Jangraa $A$, and Lahkara $M$ (2015): Mangiferin ameliorates aluminium chloride-induced cognitive dysfunction via alleviation of hippocampal oxido-nitrosative stress, proinflammatory cytokines and acetylcholinesterase level. Journal of Trace Elements in Medicine and Biology, 31:107-112.

40. Kaur P and Sodhi RK (2015): Memory recu- perative potential of rifampicin in aluminum chloride-induced dementia: role of pregnane $X$ receptors. Neuroscience, 288:24-36.

41. Khalaj KM, Amiri S, Hosseinpour FMA, and Shaikhzadeh HF (2016): Comparing the effects of rivastigmin and aqueous extract of olibanum on gene expression of amyloid precursor protein in rats treated with aluminum chloride. J Police Med, 4(4):279-286.

42. Kim SH, Kandiah N, Hsu J-L, Suthisisang C, Udommongkol C and Dash A (2017): Beyond symptomatic effects: potential of donepezil as a neuroprotective agent and disease modifier in Alzheimer's disease. British Journal of Pharmacology, 174:4224-4232 .

43. Kumar A, Dogra S, and Prakash A (2009): Protective effect of curcumin (Curcuma longa), against aluminium toxicity: Possible behavioral and biochemical alterations in rats. Behavioural Brain Research, 205:384-390.

44. Kumar A, Prakash A, and Dogra S (2011): Neuroprotective effect of carvedilol against aluminium induced toxicity: possible behavioral and biochemical alterations in rats. Pharmacological reports, 63:915-923.

45. Lahiri DK and Nall C (1995): Promoter activity of the gene encoding the betaamyloid precursor protein is up-regulated by growth factors, phorbol ester, retinoic acid and interleukin-1. Mol. Brain Res., 32:233-240.

46. Lahiri DK, Chen D, Vivien D, Ge Y-W, Greig $\mathrm{NH}$, and Rogers JT (2003): Role of cytokines in the gene expression of amyloid ?-protein precursor: Identification of a 5'-UTR-Binding nuclear factor and its implications in Alzheimer's disease. Journal of Alzheimer's Disease, $5(2): 81-90$. 
47. Lakshmi BV, Sudhakar M, and Aniska M (2014): Neuroprotective role of hydroalcoholic extract of Vitis vinifera against aluminiuminduced oxidative stress in rat brain Neurotoxicology, 41:73-79.

48. Lakshmi BVS, Sudhakar M and Prakash KS (2015): Protective Effect of Selenium Against Aluminum Chloride-Induced Alzheimer's Disease: Behavioral and Biochemical Alterations in Rats. Biol Trace Elem Res, 165:67-74.

49. Lee SY, Chen SL, Chang YH, Chen PS, Huang SY, Tzeng NS, et al (2014): The effects of add-on low-dose memantine on cytokine levels in bipolar II depression: A 12-week double-blind, randomized controlled trial. Journal of Clinical Psychopharmacology, 34:337-343.

50. Liang RF, Li $W Q$, Wang $X H$, Zhang $H F$, Wang $\mathrm{H}$, Wang JX, et al (2012): Aluminiummaltolate-induced impairment of learning, memory and hippocampal long-term potentiation in rats. Ind Health, 50(5):428-36.

51. Lin WT, Chen RC, Lu WW, Liu SH and Yang FY (2015): Protective effects of low-intensity pulsed ultrasound on aluminum-induced cerebral damage in Alzheimer's disease rat model. Scientific Reports, 5:9671.

52. Lockrowa J, Bogera $\mathrm{H}$, Bimonte-Nelsonb $\mathrm{H}$, and Granholma AC (2011): Effects of longterm memantine on memory and neuropathology in Ts65Dn mice, a model for Down syndrome. Behavioural Brain Research, 221:610-622

53. Lue LF, Rydel R, Brigham EF, Yang LB, Hampel H, Murphy GM Jr, et al (2001): Inflammatory repertoire of Alzheimer's disease and nondemented elderly microglia in vitro. Glia., 35(1):72-9.
54. Lukiw WJ, Percy ME, and Kruck TP (2005): Nanomolar aluminium induces proinflammatory and pro-apoptotic gene expression in human brain cells in primary culture. $\mathrm{J}$ Inorg Biochem, 99:1895-1898.

55. Ma L, Liu W, Feng D, Han J, Li Y, Cheng Q, et al (2014): Protective effect of NMDA receptor antagonist memantine on acute lung injury in mice. Journal of Central South Medical University Sciences, 39(1):12-16.

56. McLarnon JG (2012): Microglial chemotactic signaling factors in Alzheimer's disease. Am J Neurodegener Dis, 1(3):199-204.

57. Noda M and Suzumura A (2012): Sweepers in the CNS: Microglial Migration and Phagocytosis in the Alzheimer Disease Pathogenesis. International Journal of Alzheimer's Disease, 2012(891087):11 pages.

58. Nyakas C, Granic I, Halmy LG, Banerjee P, and Luiten PG (2010): The basal forebrain cholinergic system in ageing and dementia, rescuing cholinergic neurons from neurotoxic amyloid-beta 42 with memantine. Behav Brain Res, 221:594-603.

59. Ouimet CC, Baerwald KD, Gandy SE, and Greengard P (1994): Immunocytochemical localization of amyloid precursor protein in rat brain. J Comp Neurol, 348: 244-260.

60. Patel SH, Rachchh MA, and Jadav PD (2012): Evaluation of anti-inflammatory effect of antiplatelet agent clopidogrel in experimentally induced inflammatory bowel disease. Indian J Pharmacol, 44(6):744-748.

61. Prakash D and Sudhandiran G (2015): Dietary flavonoid fisetin regulates Aluminium chloride induced neuronal apoptosis in cortex and hippocampus of mice brain, The Journal of Nutritional Biochemistry, 26(12):1527-1539. 
62. Prashar Y, Gill NS, and Perween A (2014): Ameliorative effect of lagenaria siceraria fruit in aluminium chloride induced alzheimer's disease. International Journal of Universal Pharmacy and Bio Sciences 3(5):178-196.

63. Prema A, Thenmozhi AJ, Manivasagam T, Essa MM, Akbar MD, and Akbar M (2016): Fenugreek Seed Powder Nullified Aluminium Chloride Induced Memory Loss, Biochemical Changes, A?Burden and Apoptosis via Regulating Akt/GSK3?Signaling Pathway. PLoS ONE, 11(11): e0165955.

64. Qusti SY (2017): Selenium and Melatonin Attenuates Inflammation and Oxidative Stress in the Brain of Aged Rats with Aluminum Chloride -induced Alzheimer. International Journal of Pharmaceutical Research \&Allied Sciences, 6(2):289 -772.

65. Rai S, Kamat PK, Nath C, and Shukla R (2013): A study on neuroinflammation and NMDA receptor function in STZ (icv) induced memory impaired rats. Journal of Neuroimmunology, 254:1-9.

66. Ramachandran S, Sanjay AS, and Dhanaraju MD (2013): Antiamnesic effect of Piracetam potentiated with Emblica officinalis and Curcuma longa in aluminium induced neurotoxicity of Alzheimer's disease. International Journal of Advanced Research, 1(7):185-196.

67. Rather MA, Thenmozhi AJ, Manivasagam T, Bharathi MD, Essa MM, and Guillemin GJ (2018): Neuroprotective role of Asiatic acid in aluminium chloride induced rat model of Alzheimer's disease. Frontiers in Bioscience, Scholar, 10:262-275.

68. Ravi SK, Ramesh BN, Mundugaru R, and Vincent B (2018): Multiple pharmacological activities of Caesalpinia crista against aluminium induced neurodegeneration in rats: Relevance for Alzheimer's disease. Environmental Toxicology and Pharmacology, 58:202-211.

69. Rogers JT, Leiter LM, McPhee J, Cahill CM., Zhan SS, Potter H, et al (1999): Translation of the alzheimer amyloid precursor protein mRNA is up- regulated by interleukin-1 through 5?untranslated region sequences. J. Biol. Chem., 274:6421-31.

70. Rosi S, Ramirez-Amaya V, Vazdarjanova A, Esparza EE, Larkin PB, Fike JR, et al (2009): Accuracy of hippocampal network activity is disrupted by neuroinflammation: rescue by memantine. Brain, 132:2464-77.

71. Said MM and Abd Rabo MM (2017): Neuroprotective effects of eugenol against aluminium-induced toxicity in the rat brain. Arh Hig Rada Toksikol, 68:27-37.

72. Schliebs R, Heidel K, Apelt J, Gniezdzinska M, Kirazov L, and Szutowicz A (2006): Interaction of interleukin-1? with muscarinic acetylcholine receptor mediating signaling cascade in cholinergically differentiated SH-SY5Y cells. Brain Res, 1122:78-85.

73. Schmittgen TD and Livak KJ (2008): Analyzing real - time PCR data by comparative $C(T)$ method. Nature Protocols, 3(6):1101-1108.

74. Shytle RD, Mori T, Townsend K, Vendrame M, Sun N, Zeng J, et al (2004): Cholinergic modulation of microglial activation by alpha 7 nicotinic receptors. J Neurochem., 89(2):33743.

75. Sil S, Ghosh T, and Ghosh R (2016): NMDA receptor is involved in neuroinflammation in intracerebroventricular colchicine-injected rats. J Immunotoxicol., 13(4):474-89. 
76. Singh NA, Bhardwaj V, Ravi C, Ramesh N, Mandal AKA and Khan ZA (2018): EGCG Nanoparticles Attenuate Aluminum Chloride Induced Neurobehavioral Deficits, Beta Amyloid and Tau Pathology in a Rat Model of Alzheimer's Disease. Front. Aging Neurosci., 10:244

77. Singla N and Dhawan DK (2017): Zinc Improves Cognitive and Neuronal Dysfunction During Aluminium-Induced Neurodegeneration. Mol Neurobiol, 54(1):406-422.

78. Suh D-H, Trinh HKT, Liu J-N, Pham LD, Park SM, Park H-S, et al (2016): P2Y12 antagonist attenuates eosinophilic inflammation and airway hyperresponsiveness in a mouse model of asthma. J. Cell. Mol. Med.,20(2):333-341.

79. Susmita Sil, Tusharkanti Ghosh and Rupsa Ghosh (2016): NMDA receptor is involved in neuroinflammation in intracerebroventricular colchicine-injected rats. Journal of Immunotoxicology, 13(4):474-489.

80. Taïr K, Kharoubi O, Taïr OA, Hellal N, Benyettou I, and Aoues A (2016): Aluminiuminduced acute neurotoxicity in rats: Treatment with aueous extract of Arthrophytum (Hammada scoparia). Journal of Acute Disease, 5 (6):470-482.

81. Tasi YC, Chin TY, Chen YJ, Huang CC, Lee SL, and Wu TY (2015): Potential Natural Products for Alzheimer's Disease: Targeted Search Using the Internal Ribosome Entry Site of Tau and Amyloid-? Precursor Protein. Int. J. Mol. Sci., 16:8789-8810.

82. Thenmozhi AJ, Dhivyabharathi M, Raja TRW, Manivasagam T, and Essa MM (2016): Tannoid principles of Emblica officinalis renovate cognitive deficits and attenuate amyloid pathologies against aluminum chloride induced rat model of Alzheimer's disease. Nutr Neurosci, 19:269-278.

83. Thippeswamy AH, Rafiq M, Viswantha GLS, Kavya KJ, Anturlikar SD, Patki PS (2013): Evaluation of Bacopa monniera for its Synergistic Activity with Rivastigmine in Reversing Aluminum- Induced Memory Loss and Learning Deficit in Rats. J Acupunct Meridian Stud, 6(4):208-213.

84. Tronel C, Largeau B, Ribeiro MJS, Guilloteau D, Dupont A-C and Arlicot N (2017): Molecular Targets for PET Imaging of Activated Microglia: The Current Situation and Future Expectations. Int. J. Mol. Sci., 18:802.

85. Tu X, Chen X, Xie Y, Shi S, Wang J, Chen $Y$, et al (2008): Anti-inflammatory Renoprotective Effect of Clopidogrel and Irbesartan in Chronic Renal Injury. J Am Soc Nephrol, 19: 77-83.

86. Unger C, Svedberg MM, Yu WF, Hedberg MM, and Nordberg A (2006): Effect of subchronic treatment of memantine, galantamine, and nicotine in the brain of Tg2576 (APPswe) transgenic mice. J. Pharmacol. Exp. Ther., 317:30-36.

87. Verstraeten SV, Aimo L, and Oteiza PI (2008): Aluminium and lead: molecular mechanisms of brain toxicity. Arch Toxicol, 82:789-802.

88. Wang L, Hu J, Zhao Y, Lu X, Zhang Q, and Niu $Q$ (2014): Effects of aluminium on bamyloid (1-42) and secretases (APP-cleaving enzymes) in rat brain. Neurochem. Res., 39:1338-1345.

89. Webster CM, Hokari M, McManus A, Tang XN, Ma H, Kacimi R, et al (2013): Microglial P2Y12 deficiency/inhibition protects against 
brain ischemia. PLOS ONE, 8: e70927.

90. Weyrich AS, Lindemann S, Zimmerman GA (2003): The evolving role of platelets in inflammation. Thromb Haemost, 1: 1897-1905.

91. Wu HM, Tzeng NS, Qian L, Wei SJ, Hu X, Chen SH, et al (2009): Novel Neuroprotective mechanisms of memantine: Increase in neurotrophic factor release from astroglia and antiinflammation by preventing microglial overactivation. Neuropsychopharmacology, 34:2344-2357.

92. Wu T-Y and Chen C-P (2009): Dual Action of Memantine In Alzheimer Disease: A Hypothesis. Taiwanese journal of obstetrics \& gynecology, 48(3):273-7.

93. Xiao F, Li XG, Zhang XY, Hou JD, Lin LF, Gao $Q$, et al (2011): Combined administration of D-galactose and aluminium induces Alzheimer-like lesions in brain. Neurosci Bull, 27 (3):143-155.
94. Yang X, Yuan Y, and Niu Q (2016): Effects of aluminium chloride on the methylation of app in hippocampal of rats. Wei Sheng Yan Jiu, 45(3):345-9, 355.

95. Ying-Cai N, Jian-Ming W, Miao-Xian D, Li Z, and Ning $X$ (2007): Effect of Dihuangyinzi on APP mRNA express in the beta-amyloid hippocampus injection rats. Chinese Journal of Basic Medicine in Traditional Chinese Medicine, 13:901-903.

96. Zatta P, Zambenedetti $P$, Bruna V, and Filippi B (1994): Activation of acetylcholinesterase by aluminium (III): the relevance of the metal species. NeuroReport, 5:1777-1780.

97. Zhou XY, Liao Q, Pu YM, Tang YQ, Gong X, $\mathrm{Li} J$, et al (2009): Ultrasound-mediated microbubble delivery of pigment epithelium-derived factor gene into retina inhibits choroidal neovascularization. Chinese Medical Journal, 122:2711-2717. 


\title{
الملحص العربى
}

\section{تأثير الحماية العصبية المحتمل لعقار الكلوبيدوجريل على مرض الزهايهر المستحث بكلوريد الألومنيوم فى الجرذان}

\author{
نورا العدل خلفa ، رحاب حمدى عاشورa، منى يونس يوسفb، \\ يوسف محمد مسعدc، محمد هشام دباa، فريدة هانم محمد البنام \\ قسم الفارماكولوجيا الاكلينيكية - كلية الطب - جامعة المنصورة - مصرج \\ قسيم الباثولوجى - كلية الطب - جامعة المنصورة - مصرل \\ قسه الباثولوجى الإكلينيكية - كلية الطب - جامعة المنصورة - مصرج
}

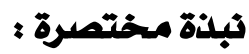

الخلفيـة والهـدف: يعد مـرض الزهـايمراحـد الأمـراض الشـائعـة سريعـة التطور التى تتتميز بـالضـمور العصبى. تساهم آليات جزيئية متعددة مثل تكوين الأميلويلد، زيادة فسفرة بروتين التاو ، انخفاض النقل العصبي الكولينيرجي ، الإجهاد التاكسدي ، والإلتهاب العصبي فى كيفية حدوث المرض. الغرض من هذه الدراسـة هو تقييهم تـأثيرالحمايـة العصبيـة المحتمل لعقار الكلوبيدوجـريل فى نهوذج الزهايهر المستحث بكلوريد الألومنيوم فى الجرذان.

الطرق: تم تقسـيم أريعـين من جـرذان سبـراج داولى من الذكور البـالغـين عشـوائياً إلى أريع مـجمـوعات (عشرة جرذان لكل منها ) : المجموعة الضابطة، مجموعة كلوريد الألومنيوم ( 100مجم / كجم عن طريق الفم)، مـجمـوعة كلوريد الألومنيوم والميـمانتين ( 10مـجم / كجم عن طريق الفم)، و مـجموعة كلوريد الألومنيوم والكلوبيدوجريل ( 00مجم / كجم عن طريق الفم). تم تناول كلوريد الألومنيوم والأدوية مرة واحسدة يوميـا لمدة 20 يوما ـ تم تقييهم التعلم المكانى والذاكرة المكانيـة عن طريق اختبـار متاهـة موريس

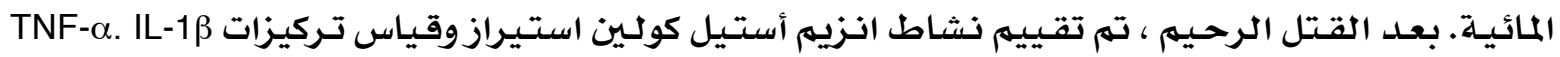

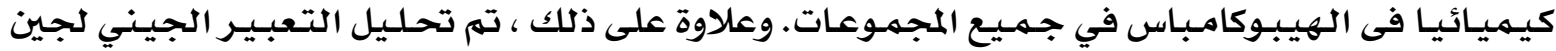

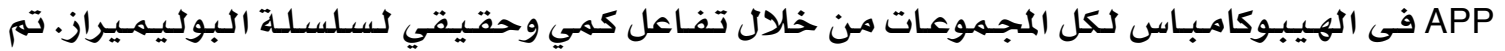
فحص نسيج الهـيبـوكامبـاس بـاثولوجيا في جـميـع المجـموعات للتحققق من وجـود لويحـات الأمسيلويد باستخدام صبغة الهيماتوكسيلين والإيوسين وصبغة الكونغو. 
النتائج: أدى تنـاول الجـرذان للكلـوبيدوجـريل مـع كلوريد الألومنيوم لمدة 20 يومـاً إلى تحسن ذو دلالة

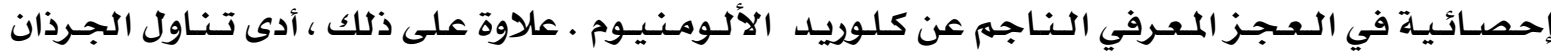
للكلوبيدوجـريل مـع كلوريد ا الألكومنـيوم إلى انخفـاض ذو دلالة احصائية في نشاط انزيهم أستيل كولين

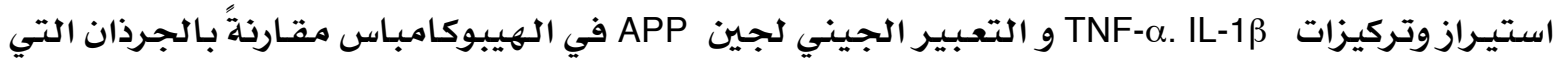
تنـاولت كلوريد الألومنيوم فقط. أدى تناول الجرذان للكلوبيدوجريل مـ كلوريد الألومنيوم إلى انخفاض

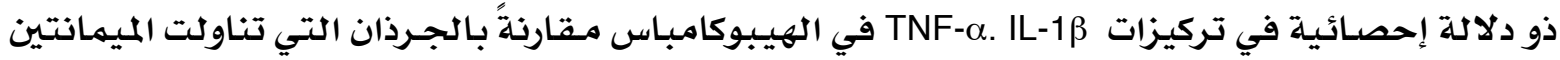
مـع كلوريد الألومنيوم. بالإضافة إلى ذلك ، قلل تناول الجـرذان للكلوبيدوجريـل مع كلوريد الألومنيوم مـن ترسب لويـحـات الأميلويـد في أنسجة الهيبـوكامباس المصبـوغة بالهيـماتوكسيلين والايوسين و الكونغو مقارنة بالجرذان التي تناولت كلوريد الألومنيوم فقط.

الخلاصسة: أظهرت هذه النـتائج أن عقـار كلوبيـدوجريل تهـكن من تحسين العهز المعـرفي النـاجم عن كلوريــ الألومنيوم في الجـرذان ـ ومن المحتـمل ان تـاثير الحهـايـة العصبـيـة لعقار الكلوبيـلدوجريل في الزهايهـرالمستحثث بكلوريـد الألومنـيوم حلدث من خلال تـاثيره المضـاد للإِلتهاب كما يـضـح من قدرته على تقليل تركيزات TNF- $\alpha$. IL-1 في الهيبـوكامباس او من خلال تـاثيره المثبط لنشـاط انزيم استيل كولين استيراز و/ أو تقليل التعبير الجيني لجين APP في الهيبوكامباس. 